\title{
Characterizing historical textiles and clothing with proteomics
}

\author{
Caroline Solazzo iD \\ Proteomics and Biomolecular Mass Spectrometry Laboratory, Museum Conservation Institute (MCI), \\ Smithsonian Institution, 4210 Silver Hill Road, Suitland, MD 20746, USA \\ solazzoc@si.edu
}

\begin{abstract}
This paper is a review of proteomics and mass spectrometric techniques used for the study of historical textiles and garments. First applied on archaeological animal fibers over a decade ago, proteomics has made important contributions to the analysis of ancient proteins and to cultural heritage studies. The field of proteomics has the potential to give a better understanding of the modes of fabrication of ancient textiles, their composition and pathways of degradation, as well as the development of animal fibers through domestication and breeding. This review summarizes current analytical methods, describes the different sources of animal fibers and their biomolecular characteristics and methods of analysis, and finally presents the main applications of proteomics to historical clothing.
\end{abstract}

\section{Caracterização de têxteis e vestuário históricos por meio da proteómica}

\section{Resumo}

Este artigo é uma revisão das técnicas de proteómica e de espectrometria de massa aplicadas ao estudo de têxteis e vestuário históricos. Inicialmente usada para o estudo de fibras animais arqueológicas há mais de uma década, a proteómica tem proporcionado contribuições importantes para a análise de proteínas antigas e para os estudos do património cultural. A proteómica tem a vantagem de oferecer uma melhor compreensão sobre os modos de fabrico de têxteis históricos, a sua composição e os processos de degradação, assim como sobre o desenvolvimento de fibras animais através de processos de domesticação e reprodução. Esta revisão apresenta os métodos analíticos actuais, descreve as diferentes fibras animais, as suas características biomoleculares e respectivos métodos de análise e, por último, apresenta as principais aplicações da proteómica ao estudo de têxteis e vestuário históricos.

\section{Keywords}

Proteomics

Mass spectrometry

Amino acids

Leather

Hair

Wool

Silk

\section{Palavras-chave}

Proteómica

Espectrometria de massa

Aminoácidos

Couro

Pelo

Lã

Seda

ISSN 2182-9942 


\section{Outline}

\section{Introduction to proteomics on textiles}

Fibrous proteins in textiles

Proteins: general introduction

Hair, wool and fur: keratinous proteins Introduction Alpha-keratin and keratin-associated proteins

Skin, hide, leather, gut: collagenous proteins Introduction Collagen proteins

Silk

Introduction

Sericin and fibroin proteins

Others: feathers, baleen, quills, sea silk

\section{Proteomics and applications to historical textiles}

Proteomics: basic principles and techniques Sample preparation: in-solution and in-gel digestions Mass spectrometric analysis

Characterization of proteins and species identification Peptide mass fingerprinting for the application to animal hair Complex samples: example of organic metal threads

Proteome characterization of domesticated vs wild species Silk Sheep wool

Protein degradation in textiles Deamidation

Photo-oxidation

\section{Conclusion}

Appendix: Guidelines for sampling of textiles for proteomics analysis

\section{Introduction to proteomics on textiles}

Since the introduction of proteomics to archaeological and cultural heritage studies in the early 2000s, proteins have been better characterized in an increasing variety of ancient substrates and materials [1-3], in particular to identify their species of origin [4]. Proteomics is a suite of techniques based on mass spectrometric analysis that studies the protein composition of tissues or other biological systems. Proteomics differs from genomics, which relates to the study of the complete set of genes from the genome and the analysis of DNA. The protein sequence is obtained from genes and the total of all proteins composing a sample or tissue is called a proteome. For historical textiles and clothing, characterizing ancient proteins has relevance for questions such as techniques of fabrication, material availability and variety, trade of materials, domestication and breeding of animals [5-10]. In addition, a thorough understanding of the factors and changes affecting proteins in fibers can be achieved using proteomics techniques [11-13]. Indeed, animal fibers undergo many processing steps that may induce damage at the protein level, and more specifically on the building blocks of proteins, the amino acids. Proteins are affected by their environment during production and collection from the animal, by the mechanical processes of producing the yarns and by the chemical treatments necessary to obtain the optimized final thread.

Proteomics techniques give a range of information from the quick snapshot of the main peptide markers present in a sample, also known as peptide mass fingerprinting (PMF) [14] to the complex analysis of the proteome (for example wool [15]) and of the possible modifications affecting proteins:

1) Peptide mass fingerprinting is an efficient method to identify keratinous tissues to species when the recognizable structural information has not survived (e.g. the scales on hair). The identification is based on the presence of specific markers (peptides obtained by digestion of proteins) [1617], and requires small amounts of samples. PMF analysis can be successful with samples that have been exposed to archaeological environments as varied as bogs and peat, waterlogged soils, anaerobic rich urban deposits, arid, permafrost and frozen soils, or preserved through mineralization and pseudomorphism.

2) In mixed or complex substrates, mass spectrometric analysis is performed after separation of the proteins and peptides (using chromatography or electrophoresis), so that identification is achieved on a maximum number of peptides, including those that bear modifications (see 4). Complex samples can be threads with multiple fiber types (e.g. dog and goat fiber blend in Coast Salish blankets [6]), or samples that contain multiple protein layers (e.g. metal threads made of an animal membrane substrate with protein binders [8]).

3) The characterization of the full proteome of animal fibers is an arduous task but one that has been facilitated in recent years by higher instrument sensitivity and increasing access to genomic information. Analysis of the proteome has the potential to reveal relationships between close species or sub-species (e.g. domesticated silk vs wild silk), and to evaluate morphological changes in fibers in correlation to expression and quantitation of proteins (e.g. fineness of wool).

4) Finally, proteomics is used for studying the degradation of proteins, which is evaluated through protein hydrolysis and chemical modifications. Many events influence the degradation of proteins: (i) processing (mordanting, dyeing, weighting, tanning, etc), (ii) interaction with other materials and products of degradation of these materials (e.g. fats, resins or other proteins), (iii) burial contexts or environmental conditions during the lifespan of the object and (iv) conservation/restoration treatments and modern display conditions of the object (pollution, light). 


\section{Fibrous proteins in textiles}

\section{Proteins: general introduction}

Proteins are made of long chains of amino acids (called residues when they are linked by peptidic bonds in the protein chain), forming polypeptides. They are macromolecules of high molecular weight, ranging from a few dozen residues (e.g keratin-associated proteins in wool) to thousands of residues for the largest proteins (e.g. heavy-chain fibroin in silk). Twenty amino acids are used to form proteins, whose sequences are encoded by the genetic code. Amino acids consist of an amine group $\left(\mathrm{NH}_{2}\right)$, a carboxyl group $(\mathrm{COOH})$ and a variable $\mathrm{R}$ group known as the side chain that gives the amino acid its specific chemical properties (Table 1). The sequence of amino acids (primary structure), through the combined properties of the R groups, determines the shape (secondary and tertiary structures) and function of the protein. Structural proteins, such as collagen in skin (e.g. leather), keratin in hair and wool, and fibroin in silk, are fibrous proteins [18] that provide mechanical support, strength, and a protec- tive framework. They have three-dimensional structures in the form of alpha-helix (alpha-keratin), beta-pleated sheets (heavy-chain fibroin), or triple helix (collagen).

\section{Hair, wool and fur: keratinous proteins}

\section{Introduction}

Animal hair is the most common proteinaceous fiber used in textiles; while the overall protein composition in hair is similar across species and consists mainly of trichocyte keratin proteins ( $\alpha$-keratin), there is a large range of fiber types that has resulted in different usages for the fibers. The fur of animals such as seal, mink or fox provides high thermal insulation by trapping air in their densely packed undercoat of very fine and short hair. In otters for instance, the density of hair and a pattern of cuticular scales that favor interlocking of hair contribute to keeping water from reaching the undercoat [19]. The coat of animals such as rabbit, sheep and especially beaver were used for felt (e.g. beaver felt hats were of high fashion during the 17th-18th c. in Europe [20]). For woven textiles, wool has been a

Table 1

List of amino acids composing proteins

\begin{tabular}{|c|c|c|c|c|}
\hline Amino acid & 3-letter code & 1-letter code & Side -chain & Property \\
\hline Alanine & Ala & A & $-\mathrm{CH}_{3}$ & Hydrophobic \\
\hline Arginine & Arg & $\mathrm{R}$ & $-\left(\mathrm{CH}_{2}\right)_{3} \mathrm{NH}-\mathrm{C}(\mathrm{NH})\left(\mathrm{NH}_{2}\right)$ & Basic, polar \\
\hline Aspartic acid & Asp & $\mathrm{D}$ & $-\mathrm{CH}_{2} \mathrm{COOH}$ & Acidic, polar \\
\hline Asparagine & Asn & $\mathrm{N}$ & $-\mathrm{CH}_{2} \mathrm{CONH}_{2}$ & Polar \\
\hline Cysteine & Cys & $\mathrm{C}$ & $-\mathrm{CH}_{2} \mathrm{SH}$ & Polar \\
\hline Glutamic acid & Glu & $\mathrm{E}$ & $-\mathrm{CH}_{2} \mathrm{CH}_{2} \mathrm{COOH}$ & Acidic, polar \\
\hline Glutamine & Gln & Q & $-\mathrm{CH}_{2} \mathrm{CH}_{2} \mathrm{CONH}_{2}$ & Polar \\
\hline Glycine & Gly & G & $-\mathrm{H}$ & Hydrophobic \\
\hline Histidine & His & $\mathrm{H}$ & $-\mathrm{CH}_{2}-\mathrm{C}_{3} \mathrm{H}_{3} \mathrm{~N}_{2}$ & Basic, polar, aromatic \\
\hline Isoleucine & Ile & I & $-\mathrm{CH}\left(\mathrm{CH}_{3}\right) \mathrm{CH}_{2} \mathrm{CH}_{3}$ & Hydrophobic, aliphatic \\
\hline Leucine & Leu & $\mathrm{L}$ & $-\mathrm{CH}_{2} \mathrm{CH}\left(\mathrm{CH}_{3}\right)_{2}$ & Hydrophobic, aliphatic \\
\hline Lysine & Lys & $\mathrm{K}$ & $-\left(\mathrm{CH}_{2}\right)_{4} \mathrm{NH}_{2}$ & Basic, polar \\
\hline Methionine & Met & M & $-\mathrm{CH}_{2} \mathrm{CH}_{2} \mathrm{SCH}_{3}$ & Hydrophobic \\
\hline Phenylalanine & Phe & $\mathrm{F}$ & $-\mathrm{CH}_{2} \mathrm{C}_{6} \mathrm{H}_{5}$ & Hydrophobic, aromatic \\
\hline Proline & Pro & $\mathrm{P}$ & $-\mathrm{CH}_{2} \mathrm{CH}_{2} \mathrm{CH}_{2}^{-}$ & Hydrophobic \\
\hline Serine & Ser & $\mathrm{S}$ & $-\mathrm{CH}_{2} \mathrm{OH}$ & Polar \\
\hline Threonine & Thr & $\mathrm{T}$ & $-\mathrm{CH}(\mathrm{OH}) \mathrm{CH}_{3}$ & Polar \\
\hline Tryptophan & Trp & $\mathrm{W}$ & $-\mathrm{CH}_{2} \mathrm{C}_{8} \mathrm{H}_{6} \mathrm{~N}$ & Polar, aromatic, hydrophobic \\
\hline Tyrosine & Tyr & $\mathrm{Y}$ & $-\mathrm{CH}_{2}-\mathrm{C}_{6} \mathrm{H}_{4} \mathrm{OH}$ & Polar, aromatic, hydrophobic \\
\hline Valine & Val & $\mathrm{V}$ & $-\mathrm{CH}\left(\mathrm{CH}_{3}\right)_{2}$ & Hydrophobic, aliphatic \\
\hline
\end{tabular}


Figure 1. Type I and type II keratins from Ovis aries (sheep), showing $\alpha$-helical chains 1A, 1B, 2A, and 2B (red), linkers L1, L12, and L2, and $\mathrm{C}$ - and N-termini (black) [13].

ubiquitous fiber since the domestication of sheep thousands of years ago. Through breeding, sheep hair has developed into fine wool with a high amount of crimp that facilitates spinning of the fiber into threads. Other animals commonly used for their wool are goats (cashmere and mohair), alpaca and other camelids, and angora rabbits.

\section{Alpha-keratin and keratin-associated proteins}

Mammalian hair has three structural elements: the outer layer made of cuticle cells that overlap to create a scale pattern used for microscopic identification, the cortex made of macrofibrils and, for some species, a medulla at the core of the fiber. In sheep wool, the cortex, whose macrofibril architecture defines crimp and coarseness of fibers, is organized into three cell types: paracortex, orthocortex, and mesocortex [21-22]. The macrofibrils are composed of intermediate filaments (IFs) of trichocyte keratins arranged longitudinally, cross-linked to structurally irregular keratin-associated proteins (KAPs) that compose the matrix surrounding the IFs [23]. The keratins form a large family of proteins of acidic type Is (K31 to K40) and neutral-basic type IIs (K81 to K87), of about 400 to 500 amino acid residues. The central rod domain is a right-handed alpha-helix (segments $1 \mathrm{~A}, 1 \mathrm{~B}, 2 \mathrm{~A}$ and $2 \mathrm{~B}$ in Figure 1) interrupted by some amorphous segments called linkers (L1, L12 and L2), and terminated by a long amorphous head and tail ( $\mathrm{N}$-terminus and $\mathrm{C}$-terminus). The keratins assemble in coiled-coil heterodimers consisting of one type I and one type II proteins. Examples of sheep type I and type II proteins are given Figure 1, with the red segments indicating the alpha-helical structures. The KAPs consist of an even larger group of proteins (for example 23 families in sheep [24]) falling into three main categories: high-sulfur (HSPs), ultra-high-sulfur (UHSPs) and high glycine-tyrosine (HGTPs) proteins [24]. The hair keratins have a high content of the sulfur-containing amino acid cysteine, forming abundant cross-links (disulfide bridges) between the keratins' head and tail domains and the KAPs. Inter- and intra-molecular crosslinks of KAPs are also possible [23]. Through interactions with the keratins, the KAPs affect the mechanical properties of the fibers [24]. Both the macrofibril arrangement and the protein profile vary from species to species, implying that protein composition and expression influence fiber morphology and consequently their physical properties [25].

\section{Skin, hide, leather, gut: collagenous proteins}

\section{Introduction}

Clothing made from animal skins is present in the archaeological record in the form of hides, leather or furs (skins with hair still attached, see Hair, wool and fur). They were made into capes and cloaks, trousers, shoes, belts, and gloves, providing protection against cold, wind, and physical harm [26]. Once the skin is removed from the animal, it goes through a series of treatments to remove both the remaining fat and flesh on the internal side and the hair on the external side. One common method for dehairing is liming, an alkaline process that loosens the hair from the epidermis but also denatures and hydrolyzes keratins. After defleshing and de-hairing, the result is a raw hide that can be left untanned or turned into leather using one of several tanning or tawing methods: vegetable, chrome, alum, emulsified oils (often animal brain), or 
fish oils (chamois leather). The tanning process generates cross-linking between the collagen fibers and in some cases bonding with the tannin molecules [18], and makes the skins more flexible and resistant to putrefaction.

Collagen is the main component of hides and leather and is also the main protein group found in gut and sinew used in garments in the Arctic parts of the world [10]. Leather, parchment and gut tissues have also been indirectly used in textiles, for example in metal threads made of metal-coated organic substrates (see Complex samples: example of organic metal threads).

\section{Collagen proteins}

Collagen fibrils consist of bound tropocollagen proteins, themselves assembled from three left-handed helical polypeptide chains. The three helical chains are twisted together and stabilized by hydrogen bonds to form a right-handed triple helix. There are 28 types of collagen, of which the most abundant type in skin and bone is type I collagen, made of a triple helix of two identical alpha chains $\alpha 1(\mathrm{I})$ and one $\alpha 2(\mathrm{I})$ chain [18]. Collagen has a very repetitive pattern with abundant proline (Pro) and hydroxyproline (Hyp), and one amino acid, glycine, occurring every three residues in a Gly-X-X pattern. The small size of Gly (the simplest amino acid, Table 1) allows it to fit into the helical structure stabilized by Pro and Hyp.

\section{Silk}

\section{Introduction}

Silk is an extracellular proteinaceous fiber reeled from the cocoon of silkworms. It is primarily produced from the domesticated silkworm Bombyx mori but other species have been exploited and are referred to as wild silks (for example Tussah, Muga or Eri silk). The reeled fiber is made of two brins of highly crystalline and insoluble proteins, the fibroins. In cross-sections, B. mori's brins appear triangular while the fibers from wild silk such as Antheraea $s p$. take an elongated oval shape [18]. The fibroins are glued with sericin, a randomized amorphous coil with a high content of the amino acid serine (for example $32 \%$ in Bombyx mori), making it highly soluble. Sericin makes up $20-30 \%$ of silk but is partially or completely removed for the production of threads in a process called degumming.

\section{Sericin and fibroins}

The composition [27] and structure [28-29] of silk have been well characterized, facilitated by the full sequencing of the B. mori genome in 2004 [30-31]. The main proteins of the silk, the fibroins, come in two forms: the light (L-chain) and the heavy (H-chain) chains. In $B$. mori the L-chain is a short protein with 262 residues, while the $\mathrm{H}$-chain is a very long protein of 5263 residues made of many repetitive fragments. The high crystallinity and therefore strength of silk is due to the presence in the
$\mathrm{H}$-chain of residues with small side-chains, glycine (46\%), alanine (30\%) and serine (12\%), forming the hexapeptide repeat Gly-Ala- Gly-Ala-Gly-Ser (GAGAGS). The tyrosine(Y)-containing blocks (such as GAGAGY or GAGAGVGY) form semicrystalline regions. The H-chain is thus made of 12 hydrophobic crystalline regions (GAGAGS/GY-(X)-GY) separated by 11 amorphous hydrophilic regions $\left(\mathrm{GT}-(\mathrm{X})_{\mathrm{n}}-\mathrm{GT}\right)$ containing residues with large side-chains [32-33], and hydrophilic head and tail regions [28]. These amorphous regions form turns resulting in an antiparallel $\beta$-pleated sheet secondary structure [29] where protein chains are held together by noncovalent interactions, notably hydrogen bonding [18]. The H-chain is linked to the small globular L-chain fibroin by a disulfide bridge between Cys-20 (H-chain) and Cys-172 (L-chain) [33-34]. Finally, a glycoprotein (fibrohexamerin P25) completes the fibroin structural arrangement, incorporated once in every six H-chainL-chain dimers through hydrophobic interactions [35]. The role of the glycosylated protein is to maintain the structure of the H-L unit, preventing denaturation [36].

\section{Others: feathers, baleen, quills, sea silk}

Alpha-keratin is the primary component of hair, but also of horn, hoof, baleen, quill and nail. Baleen was historically in great demand from the 17th to the 19th centuries as a support element in dresses, skirts and corsets. Recently the peptide mass fingerprinting method was applied to baleen from ten different species of whales and molecular markers were determined for each species, including species-specific markers [37]. The technique could be used to determine the source of baleen in historical clothing. Other hard tissues sometimes used as elements of clothing (feathers, reptilian skin, beak, and claws from birds) are mainly made of beta-keratin, a type of protein that differs from alpha-keratins in both primary and secondary structure. More unusual and rare are threads produced from manmade fibers (e.g. from milk proteins [38]) or from byssus, the sea silk from mollusks [39]. Despite its name, the sea silk, which comes from the byssus threads from Pinna nobilis, has no relation with the traditional silk from silkmoths. Because collagen has been identified in other byssal threads from marine mollusks (Mytilidae family), it was believed that the byssus from $P$. nobilis was also collagenous. A recent study has however demonstrated, using microscopy and amino acids analysis, that it was not the case [40].

\section{Proteomics and applications to historical textiles}

\section{Proteomics: basic principles and techniques}

Sample preparation: in-solution and in-gel digestions.

Fibrous proteins have low solubility in water. Using a variety of buffer solutions, depending on the major 
proteins present or suspected, proteins are extracted (or solubilized) from their original sample or tissue and denatured (i.e. disruption of the secondary and tertiary structures).

Wool and hair are efficiently extracted with a high concentrated solution of urea with a $\mathrm{pH}>8.0$ [41]; the disulfide bridges between cysteine's side chains are cleaved with a reducing agent, for example DTT (1,4-Dithiothreitol) or TCEP-HCl (Tris(2-carboxyethyl) phosphine hydrochloride), and reoxidation is prevented by alkylation, usually using iodoacetamide (the resulting carbamidomethylation adds a $+57.0214 \mathrm{Da}$ to each cysteine). Proteins from collagenous objects made from skin and gut tissues have often been extracted using a simple solution of ammonium bicarbonate [9, 10, 42], although solutions based on guanidine [8] and urea (unpublished data) have shown good efficiency too. The filter-aided sample preparation (FASP) method based on the anionic surfactant sodium dodecyl sulfate (SDS) buffer and ultra-filtration has also been used on ancient leather [9], but has not yet been adapted widely on ancient textiles. Silk is insoluble in water due to the compact beta-sheet arrangement of the $\mathrm{H}$-chain and does not easily denature in any common protein extraction buffer. Because silk dissolves in concentrated organic salt solutions, a common method for dissolution is to use an aqueous calcium chloride-ethanol $\left(\mathrm{CaCl}_{2} / \mathrm{EtOH} / \mathrm{H}_{2} \mathrm{O}\right)$ system heated at high temperature [12].

Proteins are then digested by a proteolytic enzyme (usually trypsin) that cleaves proteins at the C-terminal side of arginine $(\mathrm{R})$ and lysine $(\mathrm{K})$ residues; the resulting peptides are usually short fragments of up to 20-30 residues. For silk however, the common enzymatic digestion with trypsin is inefficient on the H-chain because it has no arginine and lysine residues for trypsin digestion in the beta-sheet regions. Trypsin can only be employed for the head and tail domains, or to digest sericin, L-chain fibroin and P25. Instead, digestion of silk is best performed with chymotrypsin, which has high-proteolytic specificity in cleaving peptide bonds at the C-terminal side of tyrosine, tryptophan and phenylalanine, and to some extent leucine, methionine, alanine and aspartic and glutamic acids. Chymotrypsin is best suited for the digestive generation of peptides from the heavy chain of silk fibroin, which is particularly rich in tyrosine.

Digestion is performed either in-solution (some methods of fractionation including strong and weak ion exchange, reverse-phase and size-exclusion chromatography can be employed prior to digestion [43], in which case the fractions are digested separately), or proteins are separated by one (1D) or two dimension (2D) gel electrophoresis and digested from the bands or spots formed on the gels (in-gel digestion). The common 1D separation technique is sodium dodecyl sulfate polyacrylamide gel electrophoresis (SDS-PAGE) that uses SDS to denature proteins and a polyacrylamide discontinuous gel as separation medium [44]. Upon application of an electric field, the proteins migrate down a lane at various speeds and are separated by their molecular weight. In 2D gels, proteins are first separated linearly in the first dimension by their isoelectric point ( $\mathrm{pI}$ ), before being separated at 90 degrees by their molecular weight. The first dimension is called isoelectric focusing (IEF); protein separation operates on an immobilized $\mathrm{pH}$ gradient gel where an electric potential is applied across the gel. The proteins migrate toward the cathode (negatively charged) and are focused in the $\mathrm{pH}$ region corresponding to their $\mathrm{pI}$ (point of neutral charge of the protein). For the second dimension, the strip is treated with SDS for denaturation of the proteins and loaded onto an SDS-PAGE gel for separation by molecular weight. The result is a complex 2D map of proteins. In both $1 \mathrm{D}$ and $2 \mathrm{D}$ gels, proteins must be revealed by gel staining (e.g. Coomassie or silver staining), thus appearing as darker spots or bands that can be further excised and processed for in-gel digestion. Gel-electrophoresis techniques are more time-consuming than in-solution digestion but are advantageous for complex samples that require fractionation as the dynamic range of mass spectrometers is limited [43]: they are used to separate major from minor (lowabundance) proteins of proteomes (e.g. wool [41]), and specific proteins can be analyzed rather than the whole sample.

\section{Mass Spectrometric analysis.}

There is a large range of mass spectrometric techniques that can be applied to proteomics studies. In mass spectrometry, molecules are ionized and identified by means of their mass-to-charge ratios $(\mathrm{m} / \mathrm{z})$. The resulting mass spectra are plots of the relative abundance of ions as a function of their $m / z$ values. In MS mode, peptides are identified by their mass only; in MS/MS mode, a peptide is selected, isolated and fragmented in a collision cell, and the resulting fragments are acquired by a mass analyzer to form a spectrum that will be read as the amino-acid sequence of the peptide. The mass spectra generated are compared with protein sequences in databases.

The most common methods of ionization are matrixassisted laser desorption ionization (MALDI) and electrospray ionization (ESI) [45]. In MALDI, gas-phase ions are formed when molecules mixed with a matrix are irradiated with a laser; the matrix absorbs the laser energy and instigates ionization of molecules as singly-charged ions. MALDI is often coupled with a time-of-flight mass spectrometer (TOF-MS) in which the ions are accelerated through a fixed electric field and their time of flight to reach the detector determine their mass-to-charge ratio (heavier ions travel slower). With this mode of analysis, samples are directly deposited on the MALDI plate and mixed with the matrix (typically $1 \mu \mathrm{L}$ of analyte with $1 \mu \mathrm{L}$ of matrix such as $\alpha$-cyano-4-hydroxycinnamic acid). Most abundant or most easily ionized peptides are detected in a single mass spectrum [45], and MALDI-TOF-MS is 
therefore the method used in peptide mass fingerprinting (see Peptide Mass Fingerprinting (PMF) for the application to animal hair) for taxonomic identification of specimens $[14,45]$. Peptides can also be fragmented and identified in tandem MS mode (MALDI-TOF/TOF-MS). In ESI, the analyte is mixed with a solvent and injected through a tip, high voltage is applied to the sample which is dispersed in a spray and ions are created through desolvation (evaporation of the solvent). ESI is used for LC-MS/MS: the peptide solution (obtained from either in-solution digestion or in-gel digestion) is injected into a High Performance Liquid Chromatography (HPLC) or Ultra Performance Liquid Chromatography (UPLC) system for separation. For proteomics, the LC system is equipped with a reverse-phase column as the stationary phase and the mobile phase is a gradient of water miscible organic solvent (acetonitrile) with acidified water (e.g. $0.1 \%$ formic acid). Peptides are separated on the column by their hydrophobicity and transferred to the mass spectrometer through the ESI source. Mass spectrometers used with ESI are, for example, quadrupole-TOF instruments or Orbitraps [45]. ESI-LC-MS/MS allows characterization of more complex samples than MALDITOF and as such is preferred for studying degradation in ancient samples or for separation of complex protein samples.

\section{Characterization of proteins and species identification}

\section{Peptide Mass Fingerprinting (PMF) for the application to animal hair}

For wool and hair fibers, species identification in ancient textiles is most often based upon the species-specific pattern of the overlapping scales forming the cuticle and the diameter of fibers [46]. Using a range of microscopic techniques, the features of hair (fiber's diameter, shape and size of the scales of the cuticle, presence of medulla and its pattern) are recorded [47]. The task is painstaking and requires intense expertise and experience, as well as a large bank of references to account for inter- and intra-species variations [48]. Microscopic identification is further limited by variations between breeds, sometimes even in the fleece itself, and by the degradation of the cuticle, especially in archaeological artefacts. Other techniques have been considered for species identification of animal fibers such as DNA analysis [49] and Fourier Transform Infrared Spectroscopy FTIR [50]. The development of these techniques is often driven by commercial applications: luxurious fibers in textiles such as cashmere have an important economic value but problems of adulteration with lower-value fibers have called for accurate

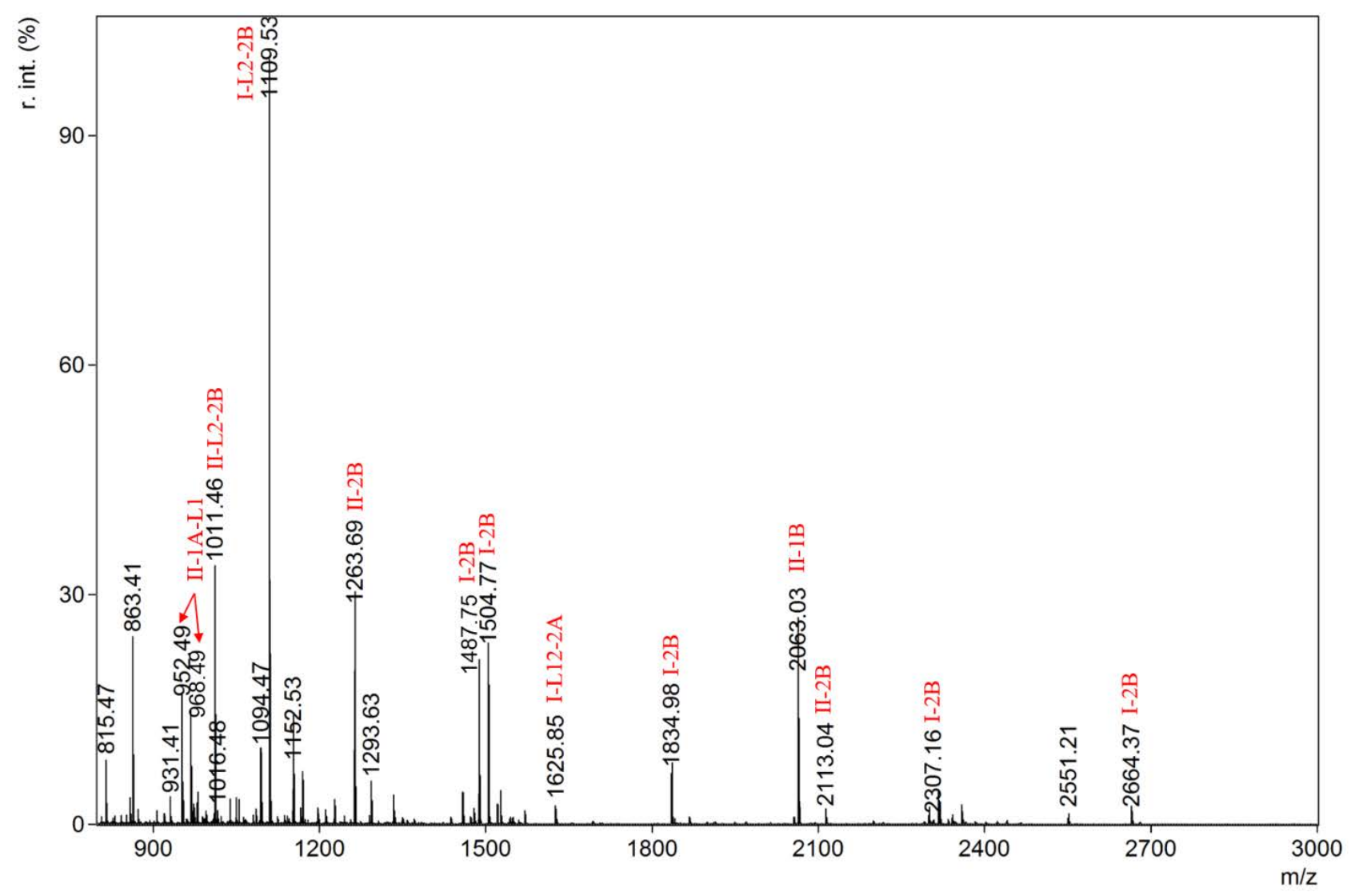

Figure 2. Merino sheep PMF obtained by MALDI-TOF-MS, showing peaks corresponding to peptides classified by their positions on the keratin sequences (Figure 1). 
Table 2

Selection of markers for species identification in a few species. Peptide $m / z$ values are indicated with carbamidomethylation on cysteine (cysteine alkylated with iodoacetamide). For full results, additional species, and description of the peptides, see Solazzo [16, 17, 37].

\begin{tabular}{|c|c|c|c|c|c|c|c|c|c|c|}
\hline Peptide & Human & Sheep & Goat & Cow & Alpaca & Dog & Bear & Beaver & $\begin{array}{l}\text { Baleen } \\
\text { (bowhead) }\end{array}$ & Opossum \\
\hline I-L12_2A & 1625.85 & 1625.85 & 1625.85 & 1625.85 & 1625.85 & 1625.85 & 1625.85 & 1625.85 & 1655.82 & 1669.87 \\
\hline $\mathrm{I}-2 \mathrm{~B}$ & 1848.99 & 1834.98 & 1834.98 & 1834.98 & 1834.98 & 1848.99 & 1848.99 & 1848.99 & 1843.95 & 1848.99 \\
\hline $\mathrm{I}-2 \mathrm{~B}$ & 2307.18 & 2307.18 & 2307.18 & 2307.18 & 2258.16 & 2305.13 & 2319.15 & 2307.18 & & 2318.20 \\
\hline $\mathrm{I}-2 \mathrm{~B}$ & 2593.35 & 2664.37 & 2691.36 & 2576.31 & 2583.35 & 2592.29 & 2636.33 & 2638.30 & 2664.37 & 2728.35 \\
\hline II-1A_L1 & 968.49 & $\begin{array}{l}952.50 / \\
968.49\end{array}$ & $\begin{array}{l}952.50 / \\
968.49\end{array}$ & 968.49 & 968.49 & 1041.49 & 1041.49 & 1041.49 & 1041.49 & 1041.49 \\
\hline II-1B & $\begin{array}{l}2007.99 / \\
2136.09\end{array}$ & $\begin{array}{l}2063.03 / \\
2191.12\end{array}$ & $\begin{array}{l}2063.03 / \\
2191.12\end{array}$ & $\begin{array}{l}2063.03 / \\
2191.12\end{array}$ & $\begin{array}{l}\text { 2063.03/ } \\
2191.12\end{array}$ & $\begin{array}{l}2035.98 / \\
2164.08\end{array}$ & $\begin{array}{l}2035.98 / \\
2164.08\end{array}$ & $\begin{array}{l}2035.00 / \\
2163.09\end{array}$ & $\begin{array}{l}2063.03 / \\
2191.12\end{array}$ & $\begin{array}{l}2035.00 / \\
2163.09\end{array}$ \\
\hline II-2B & 2043.99 & 2113.05 & 2113.05 & 2113.05 & 2101.02 & 2072.02 & 2088.02 & $\begin{array}{l}2071.99 / \\
2088.02\end{array}$ & & 2101.02 \\
\hline II-2B & 1263.69 & 1263.69 & 1263.69 & 1263.69 & 1263.69 & 1263.69 & 1263.69 & 1263.69 & 1263.69 & 1235.69 \\
\hline
\end{tabular}

methods for the identification and quantitation of hair fibers. Towards this goal, methodologies based on quantitative proteomics have also been developed [51-52]. For ancient textiles, DNA and FTIR are of limited interest: FTIR spectroscopy lacks specificity [50], while DNA recovery is generally inadequate in wool and may be further hampered by alterations due to degradation of the wool, dyes and burial conditions [53]. Recently immunological techniques using enzyme-linked immunosorbent assay (ELISA) and immuno-fluorescence microscopy have been applied to both ancient wool [54-55] and silk [56-58].

Peptide mass fingerprinting for species identification relies on matching the peptidic profile of the unknown sample with a set of reference spectra, and if possible, on the identification of specific markers. The peptidic profile is a mass spectrum of peptides obtained from enzymatic digestion of proteins and identified by their mass-to-charge ratios $(\mathrm{m} / \mathrm{z})$, usually using MALDI-TOFMS. For animal hair, keratins (more abundant in hair than the KAPs) are predominantly identified on PMFs. The spectrum in Figure 2 shows some of the main peptides identified in sheep wool and classified by their positions in the sheep sequences (Figure 1). Some peaks are shared among multiple species, while some, such as the peptide at $m / z 2664$, is specific to the Ovis genus (Table 2), as well as in some baleen whales [37].

Using key markers, identification can be achieved in archaeological samples, preferably based on the detection of multiple markers, as ancient samples tend to have altered profiles compared to their modern references. Some markers can be absent, while some might contain modifications (e.g. oxidation, deamidation) that change the mass of the peptide. For these reasons, it is advantageous to use markers with known sequences, to be able to account to possible modifications. Figure 3 compares an unknown archaeological sample to the modern reference sample of black bear. While identification is possible at the genus level (bear), the archaeological profile is altered compared to the modern sample, in particular there is a loss of intensity in the peaks and increase in background noise. This reflects the degradation of the ancient sample, mostly from hydrolysis of the protein chains into shorter fragments.

PMF was first applied to ancient textiles and garments in the early study of the clothing of the Iceman Oetzi [5, 59]. Multiple animal species (such as sheep, goat, red deer) were found by analyzing the hair of different fur elements of clothing. Woolen textiles and hair have also been successfully identified when preserved in contact with copper artifacts [60], or in peat bog [7]. PMF has also been applied to collagenous tissues to identify Arctic clothing made of skin and gut tissues [10], as well as skin garments from Danish bogs [9].

Often PMF is enough to determine the origin of a material, as long as it is made of a simple substrate. If multiple proteinaceous tissues or species are used, PMF would result in incomplete profiles, often dominated by the major component. Complex substrates need to be analyzed after separation of the peptides. In a study of Coast Salish blankets, for example, a combination of MALDI-TOF/TOF-MS and nanoLC-ESI-MS/MS was used to identify dog hair mixed with mountain goat hair in the yarns of woven textiles [6]. Currently, proteomics based on nanoLC-ESI-MS/MS is being implemented at the Museum Conservation Institute for the characterization of the protein composition of organic metal threads, with a first study successfully identifying the bovine origin of a membrane thread from a 14th c. textile [8].

\section{Complex samples: example of organic metal threads}

Metal threads used in textiles exist in single strip and wire forms or as metal-wrapped threads when wound 

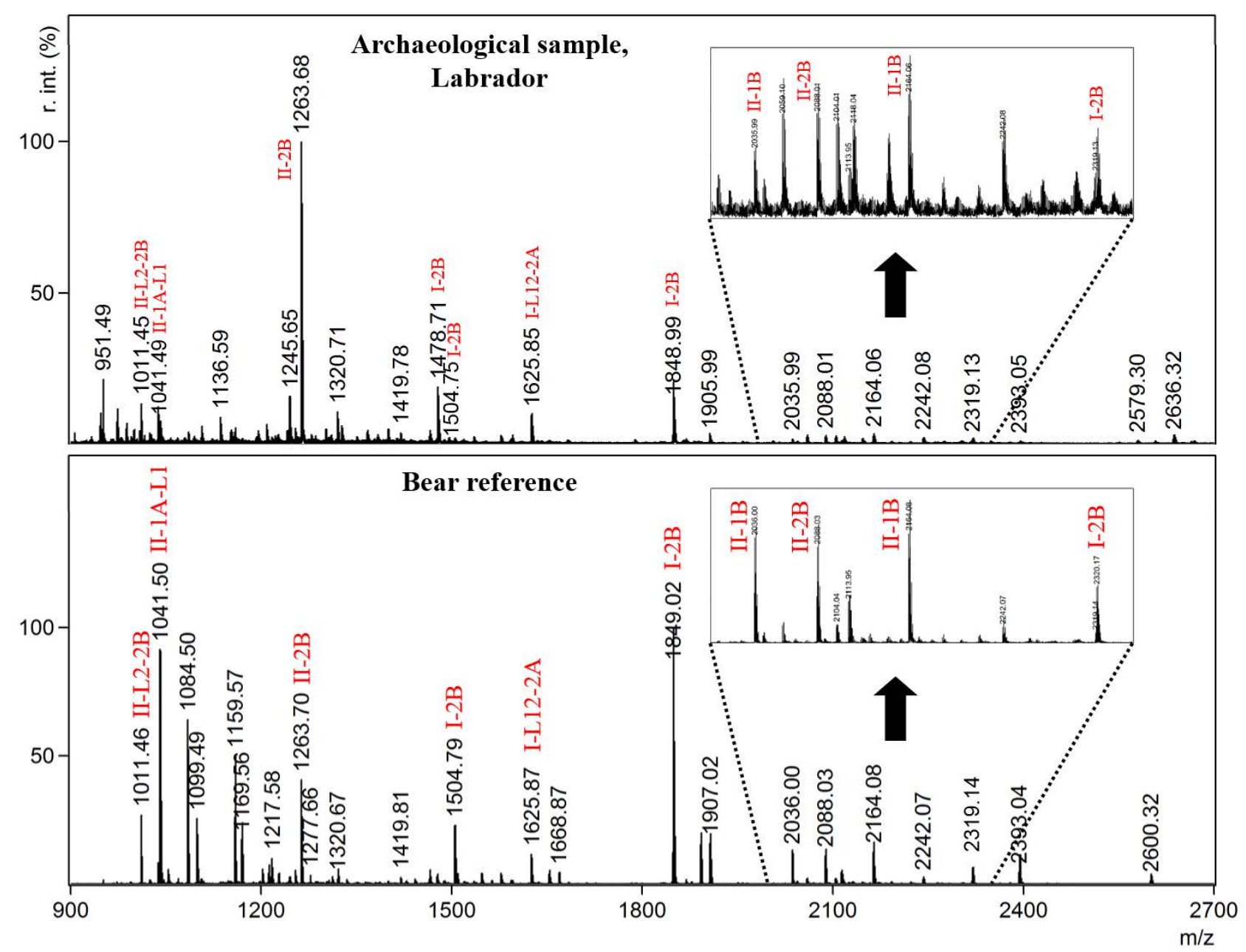

Figure 3. An archaeological sample from Labrador (top) compared to the reference sample of black bear (bottom) with all peaks allowing identification to the species.

around a fiber core (for example silk, linen) [61]. Some metal threads were made with an organic substrate, either cellulosic (paper) or proteinaceous (leather, parchment or membranous tissues, often the stomach or intestinal walls of animals), the latter type often referred to as membrane metal threads. These threads were popular since, necessitating less metal to be made, they were more economical and lightweight [62]. The metal (most frequently gold, silver or alloys of gold and silver) was applied on the organic substrate using either an additional adhesive (bole, glue, gum, or eggs) or the natural exudates of the substrate [63]. The metal-coated substrate was then cut into thin strips, used as such or wound around a core yarn.

Membrane metal threads were made and/or used in many localities, from Europe to the Middle East, to Central and East Asia, for most of the medieval period, and possibly beyond that. For instance, metal threads made on leather were still used in the construction of Chinese Children hats from the turn of the 20th c. (unpublished data, and [64]). Metal-coated leather threads might have arrived from the Far East as early as the 10th c. in Europe and lasted until the 16th c [61]. Membrane threads are believed to have appeared around the 11-12th c. and originated from Byzantium, or on/through the island of Cyprus, subsequently being referred as "Cyprian gold thread" (or "Cyprus gold") [62, 65]. From Southern Europe, membrane metal threads spread north to Italy, Germany and other countries, but there has been much speculation about whether the threads were imported or their production was established in European workshops and if so, when and where. Supposedly, the threads from Cyprus were of finer quality than the ones from European workshops [65].

Járó et al. [65] examined gilt membrane threads in order to categorized them by location and date. In their study from 1988, the width of the strips was measured in over 40 membrane threads from Italy, Germany and Hungary, and ranged from $0.30 \mathrm{~mm}$ to $1.30 \mathrm{~mm}$. The narrowest strips were generally found in weavings from the 14th c. or younger, while the widest belonged to embroideries and weavings from the 14-15th c. A comprehensive description of the different elements (the types of substrates and adhesives) composing the organic metal threads was also provided by Indictor et al. [63]. Since then, however, most analytical research has focused on the analysis of the metal composition and layering to 
detect patterns relevant to geographical origin, but little has been done to identify the organic substrates.

Proteomics is an ideal method to study these types of metal threads. Using less than $0.1 \mathrm{mg}$ of thread, proteolytic digestion can separate and identify the different proteins from both the substrate and the adhesive. Our pilot study [8] showed that an egg-based adhesive can be identified in addition to the proteins from the substrate, which, in the case of parchment, leather or abdominal and intestinal membranes, is dominated by collagen proteins. An animal glue adhesive, on the other hand, might not be identified if it originates from the same species as the substrate. In the presence of a paper substrate, a proteinaceous adhesive would be completely characterized, regardless if it is egg-based or collagen glue. Table 3 shows the main proteins identified in different collagen-based substrates. Proteomics analysis of leather indicates that de-hairing and tanning treatments not only removes the keratins from hair and the epidermis but also minor proteins such as proteoglycans and elastin [66]. In archaeological leather, mainly collagen has been detected [9].

\section{Proteome characterization of domesticated vs wild species}

\section{Proteome characterization of silk}

Most silks used in textiles belong to the bombycidae and saturniidae families. Both families contain hundreds of species, but bombycidae is best known for the Bombyx mori domesticated silk moth, also known as the true silk moth. B. mori was domesticated from the Chinese stock of its wild relative, B. mandarina that is found from North India to Japan and Russia [67]. Among the saturniidae (and saturniinae subfamily) are the giant silk moths such as the tussar moths from the Antheraea genus and the Eri silkmoth from Samia cynthia.

While proteomics has been applied to identify silk in ancient burials [68-69], the question of differentiating domesticated from wild silk in archaeological textiles is de- pendent on the availability of sequences (see Table 4). The $\mathrm{H}$-chain fibroin sequences from some wild silk species are now known but in certain species the light-chain fibroin and P25 proteins have not been detected: instead the fibroin might be formed by two polypeptides of similar size linked by a disulfide bridge (personal communication Boyoung Lee). Full sequencing of $\mathrm{H}$-chain fibroin of $B$. mandarina however would also be required to determine sequence differences with $B$. mori and look for early traces of domestication in ancient textiles. Sequences available for the shorter proteins show a high degree of homogeny with B. mori (NCBI Blast alignment): $99 \%$ with fibrohexamerin (a variation of two residues out of 220) and $100 \%$ with L-chain fibroin (protein of 262 residues in length). The one protein of sericin available in B. mandarina (sericin $1 \mathrm{~A} ; 722$ residues long) is $98 \%$ similar with $B$. mori (for a variation of 17 amino acids).

In a recent study [70], physical properties of some silkworm silks were correlated with the amino acid sequences of H-chain fibroins, comparing B. mori to Saturniidae species, including Samia cynthia ricini and Antheraea sp. for which heavy chain fibroins have been sequenced (Table 4). The primary structure (or amino acid sequence) of the domesticated and wild silks differs widely, first in the number of residues (H-chain of $B$. mori is almost twice as long as the Saturniidae species that have between 2639 residues for $A$. pernyi and 2880 for $S$. ricini), and secondly in the composition of the amino acid domains [18]. While B. mori's H-chain is made of crystalline and semi-crystalline repeats of (GA) nGX (where X is S, Y or V) [70], the Saturniidae species alternate blocks of 12-13 contiguous alanine residues with glycine-rich regions (GX, GGX and GGGX repeats). The alanine blocks were found to correlate with better thermal stability and strength, while more bulky hydrophobic residues correlate to higher brittleness but better extensibility $[18,70]$. Other properties of silks (e.g. susceptibility to photo-oxidation) and how they might influence preservation of ancient textiles could also be better addressed with characterization of the sequences.

Table 3

Summary of proteins identified in skin and intestine tissues after extraction with urea buffer, reduction, alkylation, and trypsin digestion. In bold are the major proteins identified (based on the percentage of the protein sequence identified).

\begin{tabular}{|c|c|c|c|c|}
\hline & Collagens & Proteoglycans & Cytoskeletal proteins & Smooth muscles proteins \\
\hline Rawhide & $\begin{array}{l}\alpha 1(\mathrm{I}), \alpha 2(\mathrm{I}), \alpha 1(\mathrm{II}), \\
\alpha 1(\mathrm{III}), \alpha 2(\mathrm{~V}), \alpha 2(\mathrm{VI}), \\
\alpha 3(\mathrm{VI}), \alpha 5(\mathrm{VI}), \alpha 1(\mathrm{VII})\end{array}$ & $\begin{array}{l}\text { Lumican, Decorin, } \\
\text { asporin }\end{array}$ & $\begin{array}{l}\text { Beta-actin, vimentin, } \\
\text { tubulin }\end{array}$ & $\begin{array}{l}\text { Alpha-actin, Myosin 11, } \\
\text { transgelin }\end{array}$ \\
\hline Parchment & $\begin{array}{l}\alpha 1(\mathrm{I}), \alpha 2(\mathrm{I}), \alpha 1(\mathrm{II}), \\
\alpha 1(\mathrm{III}), \alpha 2(\mathrm{~V}), \alpha 1(\mathrm{VI}), \\
\alpha 2(\mathrm{VI}), \alpha 3(\mathrm{VI})\end{array}$ & Lumican, Decorin, & Beta-actin & \\
\hline Leather & $\begin{array}{l}\alpha 1(\mathrm{I}), \alpha 2(\mathrm{I}), \alpha 1(\mathrm{III}) \\
\alpha 2(\mathrm{~V}), \alpha 3(\mathrm{~V}), \alpha 3(\mathrm{VI})\end{array}$ & & Tubulin & \\
\hline $\begin{array}{l}\text { Membrane } \\
\text { (intestine) }\end{array}$ & $\begin{array}{l}\alpha 1(\mathrm{I}), \alpha 2(\mathrm{I}), \alpha 1(\mathrm{II}), \\
\alpha 1(\mathrm{III}), \alpha 1(\mathrm{IV}), \alpha 2(\mathrm{IV}), \\
\alpha 1(\mathrm{~V}), \alpha 2(\mathrm{~V}), \alpha 2(\mathrm{VI}), \\
\alpha 3(\mathrm{VI}), \alpha 1(\mathrm{VI}), \alpha 1(\mathrm{XIV})\end{array}$ & $\begin{array}{l}\text { Decorin, Heparan } \\
\text { sulfate, mimecan, } \\
\text { lumican }\end{array}$ & $\begin{array}{l}\text { Filamin, actin, talin, } \\
\text { synemin, vinculin, } \\
\text { tubulin, vimentin, }\end{array}$ & $\begin{array}{l}\text { Myosin 11, myosin 2, myosin } \\
\text { 6, desmin, calponin, myosin } \\
\text { 9, myosin 12B, alpha actinin, } \\
\text { transgelin, tropomyosin }\end{array}$ \\
\hline
\end{tabular}


Table 4

Known sequences of silk proteins in domesticated and wild silks ( $\checkmark$ indicates at least one record exists and $\times$ that no sequence is available)

\begin{tabular}{|c|c|c|c|c|c|c|}
\hline Sequences in NCBI & $\begin{array}{l}\text { Bombyx mori } \\
\text { (Domestic silk) }\end{array}$ & $\begin{array}{l}\text { Bombyx } \\
\text { mandarina } \\
\text { (Wild silkmoth) }\end{array}$ & $\begin{array}{l}\text { Samia cynthia } \\
\text { ricini } \\
\text { (Eri silk) }\end{array}$ & $\begin{array}{l}\text { Antheraea } \\
\text { pernyi } \\
\text { (Tussah silk) }\end{array}$ & $\begin{array}{l}\text { Antheraea } \\
\text { assamensis } \\
\text { (Muga silk) }\end{array}$ & $\begin{array}{l}\text { Antheraea } \\
\text { yamamai } \\
\text { (Tensan silk) }\end{array}$ \\
\hline Fibroin heavy chain Fib-H & $\checkmark$ & $x$ & $\checkmark$ & $\checkmark$ & $\checkmark$ & $\checkmark$ \\
\hline Fibroin light chain Fib-L & $\checkmark$ & $\checkmark$ & $x$ & $x$ & $x$ & $x$ \\
\hline Sericin & $\checkmark$ & $\checkmark$ & $x$ & $x$ & $x$ & $\times$ \\
\hline P25 & $\checkmark$ & $\checkmark$ & $x$ & $x$ & $x$ & $x$ \\
\hline
\end{tabular}

\section{Proteome characterization of sheep wool}

European sheep is descended from the Asiatic mouflon and was domesticated about 10,000 years ago in the Middle-East [71]. Through selection, certain valuable traits appeared (e.g. decrease of natural shedding, white-colored coat) [71] and led to breeds dedicated to the production of wool. Mammals have two types of coats, an outer coat of coarse guard hairs providing mechanical protection and the inner coat of short and fine hair that provides thermal protection. Breeds selected for their fiber no longer have guard hairs but a single coat of fibers with similar physical characteristics [72]. Breeding also resulted in the development of finer wool, higher yield of wool and a wide range of wool varieties. The merino sheep, which was bred in Spain after the introduction in the 12th c. of sheep from North Africa, has some of the finest wool produced commercially today [73]. As in the past, the value of modern wool is grossly related to fiber diameter (finer fibers produce finer yarn), and to a lesser extend to other factors such as staple strength and length, crimp (waviness), and color. Changes in the types and qualities of wool available at different periods in different regions have been recorded both by historians researching documentary sources [7374] and by archaeologists working on the excavated textiles [75-76] using the distribution of fiber diameters to classify medieval wool into seven different fleece types [77].
Wool is mainly protein; the types and relative proportions of different proteins in the wool fiber govern its properties, or phenotype. Ultimately, it is the proteome and not the genome that governs the quality of the wool. Proteomics can attempt both qualitative and quantitative comparisons of the protein composition of the wool fibers themselves. By using 2D-electrophoresis, the protein composition of wool is revealed on maps where keratins and KAPs are clustered in specific positions. In the high molecular mass region, a tight cluster of spots corresponding to acidic type I keratins is visible at low $\mathrm{pH}$, while the type IIs appear as a long string of spots over a higher $\mathrm{pH}$ range [24]. The content of these proteins seems to vary little between breeds of sheep [78]. At lower molecular mass, and with lower intensities are scattered the spots corresponding to KAPs (Figure 4). Early research combining 2DE with MALDITOF has suggested that the high-sulfur KAPs (HSPs) may play a role in fiber curvature or crimp [79- 80]. In a study comparing Merino, Romney and Corriedale sheep, differences were observed in the KAP1 HSP family, with a pattern of spots significantly different for Merino [24, 78]. Figure 4 shows an increasing intensity of spots in the HSP region from mouflon to Merino (Soay, a feral type of sheep, is shown here as intermediary between wild sheep and merino wool). Differences are also apparent in the HGTP region with different sets of proteins present for
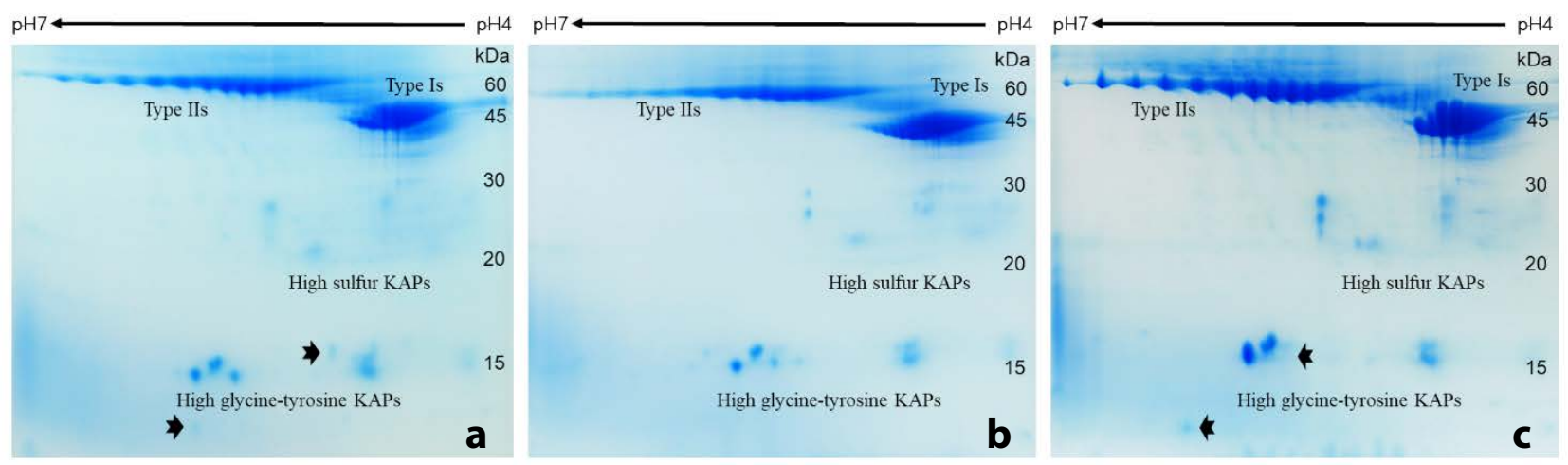

Figure 4. 2DE maps of $a$ ) mouflon, $b$ ) Soay sheep and c) Merino sheep (Caroline Solazzo, unpublished data). 
each breed (arrows pointing to spots present or absent, Figure 4). HGTPs are found to be preferentially expressed in the orthocortex and an increase of these proteins may be related to decrease in crimp frequency [24].

\section{Protein degradation in textiles}

Textiles made from animal fibers are some of the most fragile artefacts to handle and preserve. Degradation might start during processing of the fibers as some of the treatments can be harsh to proteins. Frequent forms of degradation are protein chain breakage from hydrolysis and chemical modifications such as oxidation that can further make the protein chains susceptible to breakage. For archaeological textiles, deterioration is dependent on burial conditions (soil composition, $\mathrm{pH}$, temperature, oxygen content, contact with wood coffins, metals, etc.), and on how these environmental factors regulate microbial activity. In wool, the presence of cystine, formed by disulfide bridges between cysteines, confers high resistance to chemical degradation. Keratins are therefore primarily degraded in soil via specialized keratinolytic microorganisms, as they produce enzymes capable of denaturing proteins and of breaking the disulfide bridges, necessary steps for proteolytic enzymes to access and attack keratin [11]. Wool, however, survives well in cold wet and hot arid environments, waterlogged soils, peat bogs and salt-saturated soils, when bacterial and fungal activity is reduced.

Even if physical damage is not directly observable, changes happen at the amino acid residue level and can still create long-term damage. Some studies have aimed at monitoring these changes to classify damage and anticipate the preservation of textiles. Physicochemical damage of wool and silk in indoor environments was assessed using dynamic mechanical thermal analysis (DMTA) together with thermogravimetry (TG) and differential scanning calorimetry (DSC) [81]. Cystine conversion into oxidation products such as cysteic acid in wool has been followed by attenuated total reflectance-Fourier transform infrared (ATR-FTIR) spectroscopy [82] and near infrared spectroscopy (NIR) [83]. Fibroin degradation in silk has been assessed by ATR-FTIR [84], NIR and High Performance Size Exclusion Chromatography (HPSEC) [85-86]. Assessment of oxidation through changes in amino acid composition has also been proposed using amino acid analysis [87]. In addition to these techniques, proteomics can be a powerful tool to determine precisely which amino acids are modified and/or which proteins or sections of proteins have been degraded [11]. Modifications to the fiber's chemical structure made after the fiber has been separated from the living animal can be specifically searched for by database search engines, or automatically identified through integrated searches (for example by using error tolerant) [3]. Two types of modifications occurring on animal fibers are presented here: deamidation and photooxidation.

\section{Deamidation.}

Protein deamidation, the process by which glutamine $(\mathrm{Gln} / \mathrm{Q})$ and asparagine $(\mathrm{Asn} / \mathrm{N})$ are converted into glutamic (Glu/E) and aspartic (Asp/D) acids (resulting in a mass shift of $+0.984 \mathrm{Da}$, Figure 5), has been identified as an important biomolecular marker of the deterioration and natural aging of proteins in artistic and archeological materials [88-90]. Deamidation affects all protein fibers that contain glutamine and asparagine. In silk, less than $1 \%$ of all amino acids residues in the $\mathrm{H}$-chain fibroin are $\mathrm{N}$ and Q, and they are mostly located in the amorphous head and tail regions, in contrast to the L-chain where almost $13 \%$ are $\mathrm{N}$ and $\mathrm{Q}$, making this protein more amenable for deamidation studies. In collagen, glutamine has mostly been targeted in studies of bones because the turnover rate of glutaminyl residues is slower than that of asparaginyl residues [91]. Deamidation has been observed in a 200year old skin kayak [10] but has not yet been studied in other skin garments. In hair's IF proteins, asparagine and glutamine are prevalent amino acids and constitute an important way to look at ageing and degradation of ancient wool and hair proteins. In sheep, for example, $\mathrm{N}$ and Q make up on average $14 \%$ of the type I proteins and $10 \%$ of the type IIs. Through the introduction of negative charges, deamidation creates extensive disruption on the three-dimensional structure, resulting in denaturation of the $\alpha$-helices and eventually affecting the strength and appearance of textiles. Deamidation is influenced by $\mathrm{pH}$ and temperature, but other parameters such as humidity and the structural integrity of the protein also play a role. In a study on deamidation of wool [13], we demonstrated that deamidation in wool models was time-dependent in a controlled environment but rates of deamidation were influenced by primary structure (neighboring amino acids) as well as higher order structures of proteins (the alphahelical structure), thus showing that peptides had very different rates of deamidation. On archaeological wool, the study highlighted the effect of the local environment and found that deamidation correlated poorly with age of samples. Predominance of deamidation on glutamine rather than asparagine in archeological wool samples was attributed to a higher abundance of $\mathrm{Q}$ in the $\alpha$-helical core domain of keratins, neighboring residues and steric hindrance preventing deamidation of $\mathrm{N}$. In acidic soils that favor wool preservation, direct hydrolytic deamidation of glutamine is thus facilitated [13]. In a subsequent study looking at deamidation in wool mineralized by copper ions, we found that the more mineralized the fabric was, the less deamidated it was, indicating that the presence of copper corrosion products inhibited deamidation. In nonmineralized samples, deamidation proceeded at a rate imposed by the local environment [60].

\section{Photo-oxidation}

Photodegradation is a major issue that affects textiles made of protein fibers such as wool and silk 


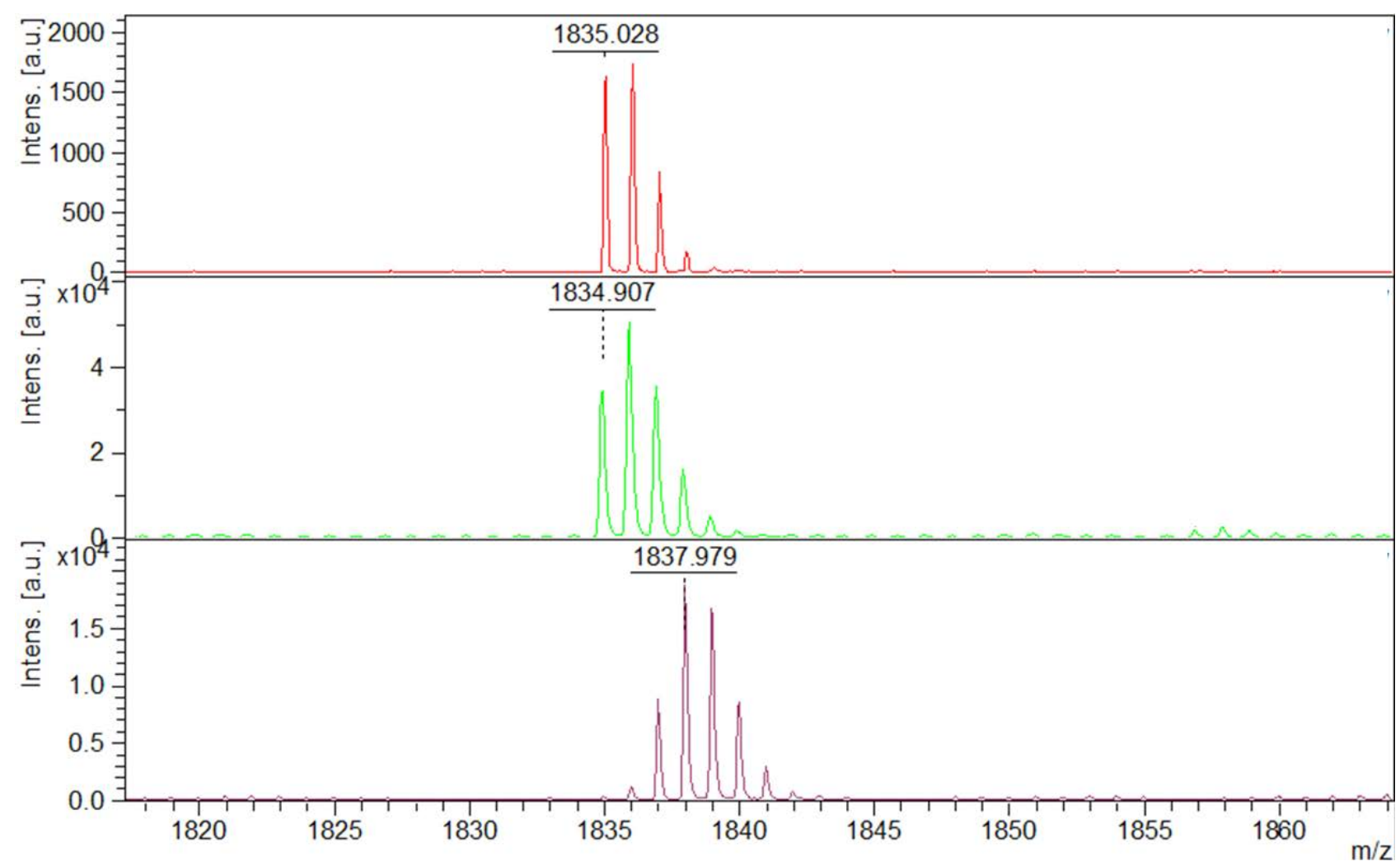

Figure 5. Deamidation of peptide $m / z 1834.98$ in modern sheep wool (top, no deamidation) and in archaeological samples, with low deamidation (middle) and high level of deamidation (bottom).

as they tend to discolor or yellow when exposed to UV light. Photodegradation not only leads to yellowing or alteration of the original color but also affects other physical properties of the fabric, such as strength and elasticity. In museums, preventive measures can be taken to mitigate the damage resulting from light exposure. However, understanding the mechanisms that lead to photodegradation of protein fibers can help to prevent further damage due to weakening of the protein chains from past exposure. Quantitative proteomics techniques could also help in better quantifying the damage and compare textiles or threads from within the same textile.

Photo-oxidation is initiated via radical species that react with atmospheric oxygen and produce peroxide radicals. Reactive oxygen species (ROS) attack both amino acid residue side-chains and the protein backbone itself. Photo-oxidative damage is caused by the accumulation of chemical modifications at the amino acid residue level that lead to a range of oxidation products, including chromophores responsible for changes in coloration. In addition, photodegradation leads to peptide chain scission, as well as reduction of disulfide bridges. In wool, cystine is oxidized, through the intermediate products sulfenic and sulfinic acids (both unstable), into cysteic acid, although other factors than UV light can contribute to cystine oxidation. Amino acid residues with aromatic side-chain groups (phenylalanine, tyrosine and tryptophan) are better markers of photo-oxidation due to the susceptibility of the aromatic groups to oxidation [92]. In archaeological wool, tryptophan and tyrosine are the main amino acids modified by photo-oxidation [93], while in silk photooxidation is directed mainly at tyrosine that is far more predominant (5\% of the $\mathrm{H}$-chain fibroin) [12]. Both tryptophan and tyrosine are oxidized through a cascade reaction that starts at single oxidation $[\mathrm{W}+\mathrm{O}]$ and $[\mathrm{Y}+$ $\mathrm{O}]$, followed by double oxidation $[\mathrm{W}+2 \mathrm{O}]$ and $[\mathrm{Y}+2 \mathrm{O}]$, to more complex products of oxidation and chromophores primarily responsible for yellowing, among them kynurenine $[\mathrm{W}+\mathrm{O}-\mathrm{C}]$ and hydroxykynurenine $[\mathrm{W}+2 \mathrm{O}$ - $\mathrm{C}]$, and quinone $[\mathrm{Y}+\mathrm{O}-2 \mathrm{H}]$ and hydroxyquinone [Y $+2 \mathrm{O}-2 \mathrm{H}][92,94]$. Irradiation with UV light of undyed and unpigmented wool showed a gradual increase in oxidation products in keratins over a 48h exposure [93]. Similarly, for untreated silk proteomics data showed a sharp increase in the formation of quinone-based tyrosine derivatives after UV ageing that correlated well with an increase in yellowing and loss of tensile strength.

Not only the length and intensity of UV light exposure produce long-term damage, the treatment of fibers with dyes, mordants, or in the case of silk, weighting agents, can also influence photodegradation positively or negatively, either by improving the photostability of the wool or by increasing the level of phototendering resulting in loss of strength and flexibility. UV radiation is absorbed by dye molecules, resulting in dye chromophores being destroyed and fading. In wool for instance, more photo-oxidation was measured by proteomics on weld-dyed samples after $48 \mathrm{~h}$ of UV exposure than on madder-dyed samples, but 
the addition of alum mordant to madder increased the photo-oxidation [93]. The presence of trace metals (for example iron and copper), that increases the production of hydroxyl radical, influences wool photostability and accelerates photoyellowing. In tin-weighted silk, more tyrosine oxidation was measured after UV exposure compared to unweighted silk, although when silk was treated with sodium tin(IV)aluminophosphosilicate derivatives, fewer peptides were observed, most likely from cross-linking, induced for example by the formation of dityrosine [12].

\section{Conclusion}

Since the introduction of proteomics to the characterization and identification of fibrous proteins, the technique has shown a promising future for the study of ancient textiles and garments. Current and future applications to archaeological and historical textiles may be further improved by: (1) the development of analytical techniques that include novel extraction protocols, sample minimization, and mass spectrometry and instrumental developments; (2) the growth of genomics data that rapidly populate databases with ever increasing numbers of organisms' proteomes; (3) the proteomics studies on modern textiles; and (4) better collaboration between archeometrists and historians and conservators, for whom proteomics facilities might be out of reach. While this review paper barely covers the wide field of textile's proteomics, it gives an overview of the type of research that has been accomplished or is applicable to ancient textiles and clothing. The challenges linked to the fragile state of fibrous proteins and rare recovery in archaeology can be overcome, using proteomics as a powerful and complementary methodology to other techniques.

\section{Appendix: Guidelines for sampling of textiles for proteomics analysis}

\section{Handling of samples}

Protein-based samples should be handled with non-latex gloves to avoid contamination. For wool and hair samples, it is particularly important to avoid touching the samples with bare hands, due to contamination from dead human skin. The cells of the epidermis are keratinized with epithelial or cytoskeletal keratins (cytokeratins). These keratins are alpha-keratin proteins, similar to the cuticular keratins of hair. For this reason, dead skin is a very common contaminant recognizable by the persistent keratin background in proteomics analysis. Although both types of keratins share common peptides, in proteomics searches, proteins specific to human skin can be filtered out and are easily differentiated from the cuticular keratins

Minimizing contamination from human keratins is however important when working with ancient samples, so that they do not overwhelm the signal from the ancient proteins. Cytoskeletal human keratins are unavoidable, as they can get into tubes, even during sample preparation. More problematic are keratins coming from hair contamination. This type of contamination can come from human hair, or from clothing made with wool (sheep wool, cashmere, agora rabbit, etc). A few easy steps allow to avoid such unwanted materials:

- Wear gloves

- Wear long-sleeves

- Do not wear woolen, and other animal-fibers blends clothes while handling samples (angora, mohair, silk, fur, cashmere, etc...)

- Keep hair tied back or covered

\section{Storing samples}

Proteomics for textiles requires destructive sampling. As techniques develop, the sample size necessary becomes smaller and smaller. A few milligrams are required for species identification using peptide mass fingerprinting. Other proteomics analysis methods might require more, depending on the state of the sample. Textiles fragments recovered from restoration work or damaged areas can be used as long as they have not been in contact with other fabrics or other sources of contamination. Cleaning steps can be taken for very soiled and dusty samples.

Before sampling a textile, an evaluation of the threads in different areas should be undertaken to determine the best sampling strategy. If possible, multiple samples should be taken, especially if threads appear different. Undyed samples are better to avoid chemical complications and damage caused by the dyes. Indigo dye, for example, is an insoluble molecular contaminant inside the fiber, even if not actually cross-linked, making the fibers and proteins harder to extract from indigo-dyed threads [11]. PMF analysis has shown successful results from threads in contact with metals [60] but not from fabrics that have evidence of being burnt or exposed to high temperature (unpublished data).

Samples can be taken as threads (a few millimeters to $0.5 \mathrm{~cm}$ ) cut with a scissor or as a piece of the fabric, in which case size will vary depending on whether the fabric is silk, wool or leather. Keep in mind that fibers might be very brittle when handling with forceps, and might become loose. Proper storage and shipping methods are:

- Whole threads, fabric pieces with good structural integrity: store in plastic tubes, eppendorfs or glass vials with wide opening, so that the sample can be taken out with forceps.

- Ancient samples tend to be brittle and fragile. If the sample is at risk of disintegrating, and fibers are becoming loose, place the sample on non-acidic paper, fold the paper and place it in a tube. Loose fibers would stick to the tube if not on paper and be difficult to reach. "Glassine" or "weighing papers" used for measuring weights provide a smooth support paper. 
- If fibers are placed directly in the tube, weight the tube before and after placing the sample to get the exact weight of the sample.

- Avoid plastic bags, unless samples are placed in folded paper and not at risk of getting loose.

\section{Acknowledgements}

The author thanks the Smithsonian Museum Conservation Institute and in particular textile conservator Mary Ballard for advice, discussions and reviewing of the manuscript, and Drs. Paula DePriest and Robert Koestler for actively supporting proteomics research at MCI. Drs. Jeff Plowman, Santanu Deb-Choudhury, Stefan Clerens, Jolon Dyer and the team at AgResearch, Christchurch, NZ, as well as Prof. Matthew Collins at the University of York, UK are also warmly thanked for supporting and contributing to a large part of the mentioned research.

\section{ORCID}

\section{Caroline Solazzo}

(iD) https://orcid.org/0000-0001-5092-0807

\section{References}

1 Giuffrida, M. G.; Mazzoli, R.; Pessione, E., 'Back to the past: deciphering cultural heritage secrets by protein identification', Applied Microbiology and Biotechnology 102 (2018) 5445-5455, https://doi.org/10.1007/s00253-0188963-z.

2 Vinciguerra, R.; De Chiaro, A.; Pucci, P.; Marino, G.; Birolo, L., 'Proteomic strategies for cultural heritage: From bones to paintings', Microchemical Journal 126 (2016) 341-348, https://doi.org/10.1016/j.microc.2015.12.024.

3 Hendy, J.; Welker, F.; Demarchi, B.; Speller, C.; Warinner, C.; Collins, M. J., 'A guide to ancient protein studies', Nature Ecology \& Evolution 2 (2018) 791-799, https://doi. org/10.1038/s41559-018-0510-x.

4 Collins, M.; Buckley, M.; Thomas-Oates, J.; Wilson, J.; Doorn, N. Van, 'ZooMS: the collagen barcode and fingerprints', Spectroscopy Europe 22 (2010) 11-13.

5 Hollemeyer, K.; Altmeyer, W.; Heinzle, E.; Pitra, C., 'Matrixassisted laser desorption/ionization time-of-flight mass spectrometry combined with multidimensional scaling, binary hierarchical cluster tree and selected diagnostic masses improves species identification of Neolithic keratin sequences from furs of the Tyrolean Iceman Oetzi', Rapid Communications in Mass Spectrometry 26 (2012) 1735-1745, https://doi.org/10.1002/rcm.6277.

6 Solazzo, C.; Heald, S.; Ballard, M. W.; Ashford, D. A.; DePriest, P. T.; Koestler, R. J.; Collins, M. J., 'Proteomics and Coast Salish blankets: a tale of shaggy dogs?', Antiquity 85 (2011) 1418-1432, https://doi.org/10.1017/S0003598X00062141.

7 Solazzo, C., 'Report on the proteomic analysis of hairs from the basketry container, the braided band and the pelt from the Whitehorse Hill cist' in Preserved in the Peat: An Extraordinary Bronze Age Burial on Whitehose Hill, Dartmoor, and Its Wider Context, ed. A. M. Jones, Oxbow Books, Oxford (2016) 274-286.

8 Popowich, A. K.; Cleland, T. P.; Solazzo, C., 'Characterization of membrane metal threads by proteomics and analysis of a 14th c. thread from an Italian textile', Journal of Cultural Heritage 33 (2018) 10-17, https://doi.org/10.1016/j. culher.2018.03.007.
9 Brandt, L. Ø.; Schmidt, A. L.; Mannering, U.; Sarret, M.; Kelstrup, C. D.; Olsen, J. V.; Cappellini, E., 'Species identification of archaeological skin objects from Danish bogs: comparison between mass spectrometry-based peptide sequencing and microscopy-based methods', PLoS ONE 9(9) (2014) e106875, https://doi.org/10.1371/journal. pone.0106875.

10 Kirby, D. P.; Buckley, M.; Promise, E.; Trauger, S. A.; Holdcraft, T. R., 'Identification of collagen-based materials in cultural heritage', Analyst 138 (2013) 4849-4858, https://doi. org/10.1039/c3an00925d.

11 Solazzo, C.; Dyer, J. M.; Clerens, S.; Plowman, J. E.; Peacock, E. E.; Collins, M. J., 'Proteomic evaluation of the biodegradation of wool fabrics in experimental burials', International Biodeterioration \& Biodegradation 80 (2013) 4859, https://doi.org/10.1016/j.ibiod.2012.11.013.

12 Solazzo, C.; Dyer, J. M.; Deb-Choudhury, S.; Clerens, S.; Wyeth, P., 'Proteomic profiling of the photo-oxidation of silk fibroin: implications for historic tin-weighted silk', Photochemistry and Photobiology 88 (2012) 1217-1226, https://doi.org/10.1111/j.1751-1097.2012.01167.x.

13 Solazzo, C.; Wilson, J.; Dyer, J. M.; Clerens, S.; Plowman, J. E.; Holstein, I. von; Rogers, P. Walton; Peacock, E. E.; Collins, M., 'Modeling deamidation in sheep $\alpha$-keratin peptides and application to archaeological wool textiles', Analytical Chemistry 86 (2014) 567-575, https://doi.org/10.1021/ ac4026362.

14 Henzel, W. J.; Watanabe, C.; Stults, J. T., 'Protein identification: the origins of peptide mass fingerprinting', Journal of the American Society for Mass Spectrometry 14 (2003) 931-942, https://doi.org/10.1016/S10440305(03)00214-9.

15 Plowman, J. E., 'Proteomic database of wool components', Journal of Chromatography B 787 (2003) 63-76, https://doi. org/10.1016/S1570-0232(02)00211-8.

16 Solazzo, C., 'Follow-up on the characterization of peptidic markers in hair and fur for the identification of common North American species', Rapid Communications in Mass Spectrometry 31 (2017) 1375-1384, https://doi.org/10.1002/ rcm.7923.

17 Solazzo, C.; Wadsley, M.; Dyer, J. M.; Clerens, S.; Collins, M. J.; Plowman, J., 'Characterisation of novel $\alpha$-keratin peptide markers for species identification in keratinous tissues using mass spectrometry', Rapid Communications in Mass Spectrometry 27 (2013) 2685-2698, https://doi.org/10.1002/ rcm.6730.

18 Florian, M.-L. E., Protein Facts: Fibrous Proteins in Cultural and Natural History Artifacts, Archetype Publications, London (2007).

19 Weisel, J. W.; Nagaswami, C.; Peterson, R. O., 'River otter hair structure facilitates interlocking to impede penetration of water and allow trapping of air', Canadian Journal of Zoology 83 (2005) 649-655, https://doi.org/10.1139/z05-047.

20 Corner, D., 'The Tyranny of fashion: the case of the felthatting trade in the late seventeenth and eighteenth centuries', Textile History 22 (1991) 153-178, https://doi.org/ 10.1179/004049691793712549.

21 Whiteley, K. J.; Kaplin, I. J., 'The comparative arrangement of microfibrils in ortho-, meso-, and paracortical cells of merino-wool fibres', The Journal of The Textile Institute $\mathbf{6 8}$ (1977) 384-386, https://doi.org/10.1080/00405007708631416.

22 Rogers, G. E., 'Electron microscopy of wool', Journal of Ultrastructure Research 2 (1959) 309-330, https://doi. org/10.1016/S0022-5320(59)80004-6.

23 Deb-Choudhury, S.; Plowman, J. E.; Rao, K.; Lee, E.; Koten, C. van; Clerens, S.; Dyer, J. M.; Harland, D. P., 'Mapping the accessibility of the disulfide crosslink network in the wool fiber cortex', Proteins: Structure, Function, and Bioinformatics 83 (2015) 224-234, https://doi.org/10.1002/prot.24727. 
24 Plowman, J. E., 'Proteomics in wool and fibre research', in Proteomics in Domestic Animals: from Farm to Systems Biology, ed. A. M. de Almeida, D. Eckersall \& I. Miller, Springer International Publishing, Cham (2018) 281-296, https://doi.org/10.1007/978-3-319-69682-9_14.

25 Thomas, A.; Harland, D. P.; Clerens, S.; Deb-Choudhury, S.; Vernon, J. A.; Krsinic, G. L.; Walls, R. J.; Cornellison, C. D.; Plowman, J. E.; Dyer, J. M., 'Interspecies comparison of morphology, ultrastructure, and proteome of mammalian keratin fibers of similar diameter', Journal of Agricultural and Food Chemistry 60 (2012) 2434-2446, https://doi. org/10.1021/jf204811v.

26 Grömer, K.; Russ-Popa, G.; Saliari, K., 'Products of animal skin from Antiquity to the Medieval period', Annalen des Naturhistorischen Museums in Wien, Serie A 119 (2017) 6993.

27 Zhang, P.; Aso, Y.; Yamamoto, K.; Banno, Y.; Wang, Y.; Tsuchida, K.; Kawaguchi, Y.; Fujii, H., 'Proteome analysis of silk gland proteins from the silkworm, Bombyx mori', Proteomics 6 (2006) 2586-2599, https://doi.org/10.1002/ pmic.200500348.

28 Jin, H.-J.; Kaplan, D. L., 'Mechanism of silk processing in insects and spiders', Nature 424 (2003) 1057-1061, https:// doi.org/10.1038/nature01809.

29 Marsh, R. E.; Corey, R. B.; Pauling, L., 'An investigation of the structure of silk fibroin', Biochimica et Biophysica Acta 16 (1955) 1-34, https://doi.org/10.1016/0006-3002(55)90178-5.

30 Mita, K.; Kasahara, M.; Sasaki, S.; Nagayasu, Y.; Yamada, T.; Kanamori, H.; Namiki, N.; Kitagawa, M.; Yamashita, H.; Yasukochi, Y.; Kadono-Okuda, K.; Yamamoto, K.; Ajimura, M.; Ravikumar, G.; Shimomura, M.; Nagamura, Y.; Shin-i, T.; Abe, H.; Shimada, T.; Morishita, S.; Sasaki, T., 'The genome sequence of silkworm, Bombyx mori', DNA Research 11 (2004) 27-35, https://doi.org/10.1093/dnares/11.1.27.

31 Xia, Q.; Zhou, Z.; Lu, C.; Cheng, D.; Dai, F.; Li, B.; Zhao, P.; Zha, X.; Cheng, T.; Chai, C.; Pan, G.; Xu, J.; Liu, C.; Lin, Y.; Qian, J.; Hou, Y.; Wu, Z.; Li, G.; Pan, M.; Li, C.; Shen, Y.; Lan, X.; Yuan, L.; Li, T.; Xu, H.; Yang, G.; Wan, Y.; Zhu, Y.; Yu, M.; Shen, W.; Wu, D.; Xiang, Z.; Yu, J.; Wang, J.; Li, R.; Shi, J.; Li, H.; Li, G.; Su, J.; Wang, X.; Li, G.; Zhang, Z.; Wu, Q.; Li, J.; Zhang, Q.; Wei, N.; Xu, J.; Sun, H.; Dong, L.; Liu, D.; Zhao, S.; Zhao, X.; Meng, Q.; Lan, F.; Huang, X.; Li, Y.; Fang, L.; Li, C.; Li, D.; Sun, Y.; Zhang, Z.; Yang, Z.; Huang, Y.; Xi, Y.; Qi, Q.; He, D.; Huang, H.; Zhang, X.; Wang, Z.; Li, W.; Cao, Y.; Yu, Y.; Yu, H.; Li, J.; Ye, J.; Chen, H.; Zhou, Y.; Liu, B.; Wang, J.; Ye, J.; Ji, H.; Li, S.; Ni, P.; Zhang, J.; Zhang, Y.; Zheng, H.; Mao, B.; Wang, W.; Ye, C.; Li, S.; Wang, J.; Wong, G. K.-S.; Yang, H., 'A draft sequence for the genome of the domesticated silkworm (Bombyx mori)', Science 306 (2004) 1937-1940, https://doi.org/10.1126/science.1102210.

32 Zhou, C.-Z.; Confalonieri, F.; Medina, N.; Zivanovic, Y.; Esnault, C.; Yang, T.; Jacquet, M.; Janin, J.; Duguet, M.; Perasso, R.; Li, Z.-G., 'Fine organization of Bombyx mori fibroin heavy chain gene', Nucleic Acids Research 28 (2000) 2413-2419, https://doi.org/10.1093/nar/28.12.2413.

33 Ha, S.-W.; Gracz, H. S.; Tonelli, A. E.; Hudson, S. M., 'Structural study of irregular amino acid sequences in the heavy chain of Bombyx mori silk fibroin', Biomacromolecules 6 (2005) 2563-2569, https://doi.org/10.1021/bm050294m.

34 Yamaguchi, K.; Kikuchi, Y.; Takagi, T.; Kikuchi, A.; Oyama, F.; Shimura, K.; Mizuno, S., 'Primary structure of the silk fibroin light chain determined by cDNA sequencing and peptide analysis', Journal of Molecular Biology 210 (1989) 127-139, https://doi.org/10.1016/0022-2836(89)90295-7.

35 S. Inoue, K. Tanaka, F. Arisaka, S. Kimura, K. Ohtomo, S. Mizuno, 'Silk fibroin of Bombyx mori is secreted, assembling a high molecular mass elementary unit consisting of H-chain, L-chain, and P25, with a 6:6:1 molar ratio', Journal of Biological Chemistry 275 (2000) 40517-40528, https://doi. org/10.1074/jbc.M006897200.
36 Zhang, P.; Yamamoto, K.; Aso, Y.; Banno, Y.; Sakano, D.; Wang, Y.; Fujii, H., 'Proteomic studies of isoforms of the P25 component of Bombyx mori fibroin', Bioscience, Biotechnology, and Biochemistry 69 (2005) 2086-2093, https:// doi.org/10.1271/bbb.69.2086.

37 Solazzo, C.; Fitzhugh, W.; Kaplan, S.; Potter, C.; Dyer, J. M., 'Molecular markers in keratins from mysticeti whales for species identification of baleen in museum and archaeological collections', PLOS ONE 12(8) e0183053, https://doi.org/10.1371/journal.pone.0183053.

38 Brooks, M. M., “"Astonish the world with. . . your new fiber mixture": Producing, promoting, and forgetting manmade protein fibers', in The Age of Plastic: Ingenuity and Responsibility, ed. O. Madden, A. E. Charola, K. C. Cobb, P. T. DePriest \& R. J. Koestler (Eds. ), Smithsonian Institution Scholarly Press, Washington (2017) 35-50.

39 Enegren, H. L.; Meo, F. (ed.), Treasures from the Sea. Sea Silk and Shellfish Purple Dye in Antiquity, Oxbow Books, Oxford (2017).

40 Diana, A.; Reguzzoni, M.; Congiu, T.; Rescigno, A.; Sollai, F.; Raspanti, M., 'The byssus threads of Pinna nobilis: A histochemical and ultrastructural study', European Journal of Histochemistry 61(4) (2017) 2779, https://doi.org/10.4081/ ejh.2017.2779.

41 Deb-Choudhury, S.; Plowman, J. E.; Harland, D. P., 'Chapter Eleven - Isolation and Analysis of Keratins and Keratin-Associated Proteins from Hair and Wool', in Methods in Enzymology, ed. M. B. Omary \& R. K. H. Liem, Academic Press, (2016) 279-301, https://doi.org/https://doi. org/10.1016/bs.mie.2015.07.018.

42 Fiddyment, S.; Holsinger, B.; Ruzzier, C.; Devine, A.; Binois, A.; Albarella, U.; Fischer, R.; Nichols, E.; Curtis, A.; Cheese, E.; Teasdale, M. D.; Checkley-Scott, C.; Milner, S. J.; Rudy, K. M.; Johnson, E. J.; Vnouček, J.; Garrison, M.; McGrory, S.; Bradley, D. G.; Collins, M. J., 'Animal origin of 13thcentury uterine vellum revealed using noninvasive peptide fingerprinting, Proceedings of the National Academy of Sciences 112(49) (2015) 15066-15071, https://doi.org/10.1073/ pnas.1512264112.

43 Feist, P.; Hummon, A., 'Proteomic challenges: sample preparation techniques for microgram-quantity protein analysis from biological samples, International Journal of Molecular Sciences 16(2) (2015) 3537-3563, https://doi. org/10.3390/ijms16023537.

44 Roy, S.; Kumar, V., 'A practical approach on SDS PAGE for separation of protein', International Journal of Science and Research 3(8) (2014) 955-960.

45 Cleland, T. P.; Schroeter, E. R., 'A comparison of common mass spectrometry approaches for paleoproteomics', Journal of Proteome Research 17(3) (2018) 936-945, https://doi. org/10.1021/acs.jproteome.7b00703.

46 Appleyard, H. M., Guide to the Identification of Animal Fibres, British Textile Technology Group, Leeds (1978).

47 Brunner, H.; Coman, B. J., The Identification of Mammalian Hair, Inkata Press, Melbourne (1974).

48 Tridico, S. R.; Houck, M. M.; Kirkbride, K. P.; Smith, M. E.; Yates, B. C., 'Morphological identification of animal hairs: Myths and misconceptions, possibilities and pitfalls', Forensic Science International 238 (2014) 101-107, https:// doi.org/10.1016/j.forsciint.2014.02.023.

49 Kerkhoff, K.; Cescutti, G.; Kruse, L.; Müssig, J., 'Development of a DNA-analytical method for the identification of animal hair fibers in textiles', Textile Research Journal 79(1) (2009) 69-75, https://doi.org/10.1177/0040517508090488.

50 McGregor, B. A.; Liu, X.; Wang, X. G., 'Comparisons of the Fourier transform infrared spectra of cashmere, guard hair, wool and other animal fibres', The Journal of The Textile Institute 109(6) (2018) 813-822, https://doi.org/10.1080/0040 5000.2017 .1372057 . 
51 Li, S.; Zhang, Y.; Wang, J.; Yang, Y.; Miao, C.; Guo, Y.; Zhang, Z.; Cao, Q.; Shui, W., 'Combining untargeted and targeted proteomic strategies for discrimination and quantification of cashmere fibers', PLoS ONE 11(1) (2016) e0147044, https:// doi.org/10.1371/journal.pone.0147044.

52 Sara, P.; Mariangela, B.; Francesca, L.; Barbara, P.; Andrea, F.; Cinzia, T.; Claudia, V.; Stefano, S., 'Identification and quantification of different species in animal fibres by LC/ ESI-MS analysis of keratin-derived proteolytic peptides', Journal of Mass Spectrometry 48(8) (2013) 919-926, https:// doi.org/10.1002/jms.3222.

53 Brandt, L.; Tranekjer, L.; Mannering, U.; Ringgaard, M.; Frei, K.; Willerslev, E.; Gleba, M.; Gilbert, M., 'Characterising the potential of sheep wool for ancient DNA analyses', Archaeological and Anthropological Sciences 3(2) (2011) 209221, https://doi.org/10.1007/s12520-011-0055-2.

54 Wang, B.; Gu, J.; You, Q.; Chen, B.; Zheng, H.; Zhou, Y.; Hu, Z., 'Preparation of artificial antibodies and development of an antibody-based indirect ELISA for the detection of ancient wool', Analytical Methods 10(12) (2018) 1480-1487, https://doi.org/10.1039/c8ay00015h.

55 Wang, B.; Gu, J.; Chen, B.; Xu, C.; Zheng, H.; Peng, Z.; Zhou, Y.; $\mathrm{Hu}, \mathrm{Z}$., 'Development of an enzyme-linked immunosorbent assay and gold-labelled immunochromatographic strip assay for the detection of ancient wool', Journal of Analytical Methods in Chemistry 2018 (2018) 2641624, https://doi. org/10.1155/2018/2641624.

56 Liu, M.; Xie, J.; Zheng, H.; Zhou, Y.; Wang, B.; Hu, Z., 'Identification of ancient silk using an enzyme-linked immunosorbent assay and immuno-fluorescence microscopy', Analytical Sciences 31(12) (2015) 1317-1323, https://doi.org/10.2116/analsci.31.1317.

57 Zheng, Q.; Wu, X.; Zheng, H.; Zhou, Y., 'Development of an enzyme-linked-immunosorbent-assay technique for accurate identification of poorly preserved silks unearthed in ancient tombs', Analytical and Bioanalytical Chemistry 407(13) (2015) 3861-3867, https://doi.org/10.1007/s00216-015-86216.

58 Liu, M.; Li, Y.; Zheng, H.; Zhou, Y.; Wang, B.; Hu, Z., 'Development of a gold-based immunochromatographic strip assay for the detection of ancient silk', Analytical Methods 7(18) (2015) 7824-7830, https://doi.org/10.1039/ c5ay01591j.

59 Hollemeyer, K.; Altmeyer, W.; Heinzle, E.; Pitra, C., 'Species identification of Oetzi's clothing with matrix-assisted laser desorption/ionization time-of-flight mass spectrometry based on peptide pattern similarities of hair digests', Rapid Communications in Mass Spectrometry 22 (2008) 2751-2767, https://doi.org/10.1002/rcm.3679.

60 Solazzo, C.; Rogers, P. W.; Weber, L.; Beaubien, H. F.; Wilson, J.; Collins, M., 'Species identification by peptide mass fingerprinting (PMF) in fibre products preserved by association with copper-alloy artefacts', Journal of Archaeological Science 49 (2014) 524-535, https://doi. org/10.1016/j.jas.2014.06.009.

61 Ackacha, M. A.; Polec-Pawlak, K.; Jarosz, M., 'Identification of anthraquinone coloring matters in natural red dyestuffs by high performance liquid chromatography with ultraviolet and electrospray mass spectrometric detection', Journal of Separation Science 26(11) (2003) 1028-1034, https://doi. org/10.1007/978-94-010-0193-9_15.

62 Karatzani, A., 'The evolution of a craft: The use of metal threads in the decoration of late and post Byzantine ecclesiastical textiles', thesis, University College London, London (2007).

63 Indictor, N.; Koestler, R. J.; Wypyski, M.; Wardwell, A. E., 'Metal threads made of proteinaceous substrates examined by scanning electron microscopy: energy dispersive X-ray spectrometry', Studies in Conservation 34 (1989) 171-182, https://doi.org/10.1179/sic.1989.34.4.171.
64 A. Cheung, 'Untold stories of traditional Chinese children's hats - blessing, crafmanship, conservation', communication, IIC-Palace Museum 2017 Hong Kong Symposium, International Institute of Conservation, Hong Kong (2017).

65 Járó, M.; Gondár, E., 'Mediaeval Membrane threads used for weaving and Embroidery', in Archaeometrical Research in Hungary, ed. M. Járó \& L. Költõ, The National Centre of Museums, Budapest (1988) 255-266.

66 Deb Choudhury, S.; Allsop, T.; Passman, A.; Norris, G. E., 'Use of a proteomics approach to identify favourable conditions for production of good quality lambskin leather', Analytical and Bioanalytical Chemistry 384(3) (2006) 723735, https://doi.org/10.1007/s00216-005-0228-x.

67 Arunkumar, K. P.; Metta, M.; Nagaraju, J., 'Molecular phylogeny of silkmoths reveals the origin of domesticated silkmoth, Bombyx mori from Chinese Bombyx mandarina and paternal inheritance of Antheraea proylei mitochondrial DNA', Molecular Phylogenetics and Evolution 40(2) (2006) 419-427, https://doi.org/10.1016/j.ympev.2006.02.023.

68 Li, L.; Gong, Y.; Yin, H.; Gong, D., 'Different types of peptide detected by mass spectrometry among fresh silk and archaeological silk remains for distinguishing modern contamination', PLoS ONE 10(7) (2015) e0132827, https:// doi.org/10.1371/journal.pone.0132827.

69 Yu, X.; Gong, Y.; Tan, P.; Shu, J.; Liu, F.; Yang, J.; Gong, D., 'Mass spectrometry analysis of textile used in decorating the coronet of Empress Xiao of the Sui Dynasty (581-618 A.D.)', Journal of Cultural Heritage 25 (2017) 185-188, https://doi. org/https://doi.org/10.1016/j.culher.2017.01.003.

70 Malay, A. D.; Sato, R.; Yazawa, K.; Watanabe, H.; Ifuku, N.; Masunaga, H.; Hikima, T.; Guan, J.; Mandal, B. B.; Damrongsakkul, S.; Numata, K., 'Relationships between physical properties and sequence in silkworm silks', Scientific Reports 6 (2016) 27573, https://doi.org/10.1038/srep27573.

71 Alberto, F. J.; Boyer, F.; Orozco-terWengel, P.; Streeter, I.; Servin, B.; de Villemereuil, P.; Benjelloun, B.; Librado, P.; Biscarini, F.; Colli, L.; Barbato, M.; Zamani, W.; Alberti, A.; Engelen, S.; Stella, A.; Joost, S.; Ajmone-Marsan, P.; Negrini, R.; Orlando, L.; Rezaei, H. R.; Naderi, S.; Clarke, L.; Flicek, P.; Wincker, P.; Coissac, E.; Kijas, J.; Tosser-Klopp, G.; Chikhi, A.; Bruford, M. W.; Taberlet, P.; Pompanon, F., 'Convergent genomic signatures of domestication in sheep and goats', Nature Communications 9(1) (2018) 813, https:// doi.org/10.1038/s41467-018-03206-y.

72 Allain, D.; Renieri, C., 'Genetics of fibre production and fleece characteristics in small ruminants, Angora rabbit and South American camelids', Animal 4(9) (2010) 1472-1481, https://doi.org/10.1017/s1751731110000029.

73 Munro, J., 'Spanish merino wools and the nouvelles draperies: an industrial transformation in the Late Medieval Low Countries', The Economic History Review 58(3) (2005) 431-484, https://doi.org/10.1111/j.1468-0289.2005.00310.x.

74 Ryder, M. L., 'The history of sheep breeds in Britain', The Agricultural History Review 12(1) (1964) 1-12.

75 Gleba, M., 'From textiles to sheep: investigating wool fibre development in pre-Roman Italy using scanning electron microscopy (SEM)', Journal of Archaeological Science 39(12) (2012) 3643-3661, https://doi.org/10.1016/j.jas.2012.06.021.

76 Rast-Eicher, A.; Bender Jørgensen, L., 'Sheep wool in Bronze Age and Iron Age Europe', Journal of Archaeological Science 40(2) (2013) 1224-1241, https://doi.org/10.1016/j. jas.2012.09.030.

77 Ryder, M. L., 'Medieval sheep and wool types', The Agricultural History Review 32(1) (1984) 14-28.

78 Flanagan, L. M.; Plowman, J. E.; Bryson, W. G., 'The high sulphur proteins of wool: Towards an understanding of sheep breed diversity', Proteomics 2(9) (2002) 1240-1246, https://doi.org/10.1002/1615-9861(200209)2:9<1240::aidprot1240>3.0.co;2-\#. 
79 E., P. J.; G., B. W.; William, J. T., 'Application of proteomics for determining protein markers for wool quality traits', Electrophoresis 21(9) (2000) 1899-1906, https://doi. org/10.1002/(sici)1522-2683(20000501)21:9<1899::aidelps1899>3.3.co;2-i.

80 Plowman, J. E.; Deb-Choudhury, S.; Bryson, W. G.; Clerens, S.; Dyer, J. M., 'Protein expression in orthocortical and paracortical cells of merino wool fibers', Journal of Agricultural and Food Chemistry 57(6) (2009) 2174-2180, https://doi.org/10.1021/jf803290h.

81 Odlyha, M.; Wang, Q.; Foster, G. M.; de Groot, J.; Horton, M.; Bozec, L., 'Thermal analysis of model and historic tapestries', Journal of Thermal Analysis and Calorimetry 82(3) (2005) 627-636, https://doi.org/10.1007/s10973-005-0943-8.

82 Odlyha, M.; Theodorakopoulos, C.; Campana, R., 'Studies on woollen threads from historical tapestries', AUTEX Research Journal 7(1) (2007) 9-18.

83 Kissi, N.; Curran, K.; Vlachou-Mogire, C.; Fearn, T.; McCullough, L., 'Developing a non-invasive tool to assess the impact of oxidation on the structural integrity of historic wool in Tudor tapestries', Heritage Science 5(1) (2017) 49, https://doi.org/10.1186/s40494-017-0162-1.

84 Garside, P.; Lahlil, S.; Wyeth, P., 'Characterization of historic silk by polarized attenuated total reflectance Fourier transform infrared spectroscopy for informed conservation', Applied Spectroscopy 59(10) (2005) 1242-1247, https://doi. org/10.1366/000370205774430855.

85 Kim, J.; Wyeth, P., 'Towards a routine methodology for assessing the condition of historic silk', e- Preservation Science 6 (2009) 60-67.

86 Hallett, K.; Howell, D., 'Size exclusion chromatography of silk: inferring the tensile strength and assessing the condition of historic tapestries', in ICOM Committee for Conservation 14th Triennial Meeting, The Hague, ed. I. Verger, James \& James - Earthscan, London (2005) 911-919.

87 Vanden Berghe, I., 'Towards an early warning system for oxidative degradation of protein fibres in historical tapestries by means of calibrated amino acid analysis', Journal of Archaeological Science 39 (2012) 1349-1359, https://doi. org/10.1016/j.jas.2011.12.033.

88 van Doorn, N. L.; Wilson, J.; Hollund, H.; Soressi, M.; Collins, M. J., 'Site-specific deamidation of glutamine: a new marker of bone collagen deterioration', Rapid Communications in Mass Spectrometry 26(19) (2012) 2319-2327, https://doi. org/10.1002/rcm.6351.

89 Leo, G.; Bonaduce, I.; Andreotti, A.; Marino, G.; Pucci, P.; Colombini, M. P.; Birolo, L., 'Deamidation at asparagine and glutamine as a major modification upon deterioration/aging of proteinaceous binders in mural paintings', Analytical Chemistry 83(6) (2011) 2056-2064, https://doi.org/10.1021/ ac1027275.

90 Simpson, J. P.; Penkman, K. E. H.; Demarchi, B.; Koon, H.; Collins, M. J.; Thomas-Oates, J.; Shapiro, B.; Stark, M.; Wilson, J., 'The effects of demineralisation and sampling point variability on the measurement of glutamine deamidation in type I collagen extracted from bone', Journal of Archaeological Science 69 (2016) 29-38, https://doi. org/10.1016/j.jas.2016.02.002.

91 Schroeter, E. R.; Cleland, T. P., 'Glutamine deamidation: an indicator of antiquity, or preservational quality?', Rapid Communications in Mass Spectrometry 30(2) (2016) 251-255, https://doi.org/doi:10.1002/rcm.7445.

92 Dyer, J. M.; Plowman, J. E.; Krsinic, G. L.; Deb-Choudhury, S.; Koehn, H.; Millington, K. R.; Clerens, S., 'Proteomic evaluation and location of UVB-induced photo-oxidation in wool', Journal of Photochemistry and Photobiology B: Biology 98(2) (2010) 118-127, https://doi.org/10.1016/j. jphotobiol.2009.11.008.

93 Solazzo, C.; Clerens, S.; Plowman, J. E.; Wilson, J.; Peacock, E. E.; Dyer, J. M., 'Application of redox proteomics to the study of oxidative degradation products in archaeological wool', Journal of Cultural Heritage 16(6) (2015) 896-903, https://doi.org/10.1016/j.culher.2015.02.006.

94 Dyer, J. M.; Bringans, S. D.; Bryson, W. G., 'Characterisation of photo-oxidation products within photoyellowed wool proteins: tryptophan and tyrosine derived chromophores', Photochemical \& Photobiological Sciences 5(7) (2006) 698706, http://dx.doi.org/10.1039/B603030K.

Received: 2018-7-5

Revised: 2018-11-14

Accepted: 2018-12-11

Online: $2019-2-14$

This work is licensed under the Creative Commons Attribution-NonCommercial-NoDerivatives 4.0 International License.

To view a copy of this license, visit http://creativecommons.org/licenses/by-nc-nd/4.0/deed.en. 